\title{
Gentleman's Agreement: The Antisemitic Origins of Restrictions on Stockholder Litigation
}

\author{
by
}

\author{
Lawrence E Mitchell*
}

In March, 1944, within a period of two days, only two weeks after its introduction in the

New York State Legislature, the legislature passed, and Governor Dewey signed, a bill that became section 61-b (now section 627) of the New York Business Corporations Law. The statute created a right for a corporation, sued derivatively by one or more stockholders who owned less than $\$ 50,000$ in value or $5 \%$ of its outstanding stock, to demand that the plaintiffs post a bond as security for the corporation's expenses, including attorneys fees. ${ }^{1}$ The first of its kind, similar statutes now exist in nineteen states. Almost every state has some form of statute restricting the standing of derivative suit plaintiffs. ${ }^{2}$

It's certainly not unusual for a state legislature to pass a statute; that's what they do. But

* John Theodore Fey Research Professor of Law, The George Washington University. My thanks go to Pat Borchers, Bill Bratton, Claire Dickerson, Tamar Frankel, Theresa Gabaldon, Robert Gordon, Michael Hausfeld, Chip Lupu, Greg Mark, Tom Morgan, Herbert Milstein, Stanley Nemzer, Hillary Sale, Herman Schwartz, Mike Selmi, Susan Stabile, Peter Swire, Bob Tuttle, David Zlotnick, and participants in the 2002 Summer Retreat of the Sloan Program for the Study of Business in Society, a George Washington University Law School workshop, and a colloquium at Rutgers (Newark) Law School. I'd also like to thank Larry Ross of the Jacob Burns Law Library who went well beyond the call of duty in assisting me, Eloise Morgan, the Bronxville, N.Y., Village historian who graciously provided me with helpful information, and Howard Zucker of the New York office of Hawkins, Delafield and Wood for information on Franklin Wood. Research help was provided by Sarah Brown Stoller, Jillian Spear, and Paul Meissner, to each of whom I'm grateful. This Article is dedicated to all of the Jewish lawyers whose struggle for acceptance and resourcefulness in adversity made it so much easier for the rest of us.

${ }^{1}$ At the same time it passed a related statute requiring that the plaintiff have held his shares at the time of the wrong complained of. Several years earlier, and under circumstances similar to those under which Section 61-b was passed, the legislature passed a statute requiring corporations sued derivatively to indemnify defendants (but not plaintiffs) who were wholly or partly successful for their reasonable expenses, including attorneys' fees.

\footnotetext{
${ }^{2}$ Deborah DeMott, Shareholder Derivative ACTIONS: LAW AND PrACTICE, §3.01, (1999).
} 
Section 61-b had a highly unusual birth. Most New York legislation originated either within the legislature, the New York Law Revision Commission, or the Judicial Council of the State of New York. In this case, none of these were even involved, and none of them were asked for their opinions. ${ }^{3}$ Moreover, the statute seems to have been opposed by all of the major bar organizations of New York City, including "the Committee on State Legislation of the New York County Lawyers' Association, the Federal Bar Association of New York, New Jersey and Connecticut, and the Law Reform Committee of the New York City Chapter of the National Lawyers' Guild." ${ }^{4}$ No hearings were held, and debate was minimal. Lawyers and judges at the time pretty much universally recognized, for reasons that shall become clear, that the statute effectively eliminated derivative suits by making them far too expensive for a plaintiff to maintain. ${ }^{5}$

Where did Section 61-b come from? It was the gift of the New York Chamber of Commerce, an organization of businessmen which had no governmental authority. Quoting from Forbes Magazine, Zlinkoff reports that "The New York State Chamber of Commerce ... is not in fact a state chamber at all and is indeed entirely different from most chambers of commerce. It is

\footnotetext{
${ }^{3}$ Sergei S. Zlinkoff, The American Investor and the Constitutionality of Section 61-B of the New York General Corporate Law, 54 Yale L. J. 352, 359 (1945).

${ }^{4}$ See George Hornstein, The Death Knell of Stockholders 'Derivative Suits in New York, 32 Cal. L. Rev. 123 (1944). The New York County Lawyers' Association was dominated by the small firm and sole practitioner Jewish bar, and the Association of the Bar of the City of New York was dominated by the large, Protestant "White Shoe" firms. Although ABCNY opposition is noted by George Hornstein, Victor House, another contemporaneous writer, notes that while the ABCNY "appears" to have opposed the legislation there was no formal record of such opposition. Victor House, Stockholders 'Suits and the Coudert-Mitchell Laws, 20 NYU L. Q. Rev. 377 (1945). Moreoever, Zlinkoff, in his very careful article, doesn't mention the ABCNY at all. The lack of formal record is significant because the Association of the Bar was dominated by the very big firm WASP lawyers who play the villain in this piece and would have no reason to oppose the legislation. Thus the lack of formal record calls into question the strength and intensity (and indeed the sincerity) of their opposition.

${ }^{5}$ Zlinkoff, supra note __ at 355; Hornstein, supra note __ at 125 . It is worth noting that at this time direct actions by stockholders against directors were rare, see e.g., Gordon v. Elliman, 119 NE 2d 331 (N.Y. 1954)(broadly holding that derivative suits were the norm) and the stockholders' class action was a thing of the future.
} 
strictly a New York organization composed very largely of extremely conservative corporation and financial interests of that City." 6 One year prior to the bill's introduction in the legislature, the Chamber of Commerce had commissioned a report that purported to study the abuses of derivative actions and to recommend reform. The report was only released simultaneously with that introduction.

One might applaud a policy that restricted stockholder litigation to those stockholders who demonstrably had a significant financial interest in the corporation. It is, after all, a way of deterring unworthy suits. One might also take the same attitude towards Justice Rehnquist's only securities law opinion in his thirty years on the Supreme Court, the 1975 Blue Chip Stamps v. Manor Drug Stores ${ }^{7}$, which in a different way imposed important limitations on the ability of plaintiffs to sue corporations for securities fraud and began three decades of Supreme Court jurisprudence that imposed increasingly tight restrictions on plaintiffs. And one might even approach with a similar perspective the so-called Pivate Securities Litigation Reform Act of $1995^{8}$, which grew out of the ill-conceived Contract with America and which has created the embarrassing situation for an irate Congress that it may well make it difficult for Enron stockholders to recover their losses.

One might approach these restrictions with this attitude. One might see them as a legitimate attempt to protect an otherwise helpless corporate America from the pernicious threat of greedy plaintiffs' lawyers who promiscuously file lawsuits and in so doing damage stockholder

\footnotetext{
${ }^{6}$ Sergei Zlinkoff, supra note __ at 360, n. 34.

7421 U.S. 723 (1975).

${ }^{8}$ P.L. 104-67 (1995).
} 
interests, interfere with corporate efficiency, and embarrass and discourage innocent directors and officers. And in an age in which a small handful of very wealthy plaintiffs' firms seem to form a litigation cartel, one might have a point. ${ }^{9}$

But there's a different perspective from which one could approach these doctrinal developments, and it doesn't take a lot of evidence to demonstrate its potency. The 1944 Act was, I shall argue, adopted as a proximate (but almost certainly not the sole proximate) result of deeply ingrained antisemitism in the New York bar and corporate world, antisemitism which not only colored their approach to these issues but created the very structural conditions which made the argument supporting the statute seem persuasive. ${ }^{10}$ While hardly a monocausal explanation for the statute or the attitude towards stockholder suits that motivated it (strike suits do, after all, occur), it is at a minimum the template upon which these restrictions were built. It is a particularly urban and eastern form of antisemitism whose attitude and structural consequences demonstrably persisted well into the 1960s. There even are hints that it lurked behind Rehnquist's rhetoric in Blue Chip Stamps (rhetoric found nowhere in the briefs). And that ingrained, if no longer easily visible, antisemitism, animates our contemporary attitude toward stockholder suits and plaintiff's lawyers, an attitude that motivated the passage of the 1995 Act. It continues to poison the way we think about stockholder suits today.

One doesn't have to look far for the evidence. In fact the very genesis of this Article is the

${ }^{9}$ Although The Wall Street Journal recently noted that litigation has become a far more profitable enterprise for stockholders. Michael Orey, Cashing in on Stockholder Suits, The Wall Street Journal, April 25, 2002 , D.1.

10 An interesting discussion of the possibilities available to Jewish lawyers in the 1940s is provided in JEWISH LAW PROFESSORS TALK, published by B'nai B'rith in a series counseling Jewish students contemplating professional careers. LAW PROFESSORS TALK: A STUDY OF DISCRIMINATION IN THE EMPLOYMENT OF JEWISH GRAduATES OF LAW Schools (B'nai Brith Vocational Service Bureau, 1949). That the law professors were too 
tone of judicial opinions that have applied the security-for -expense statute, as well as the tone of opinions like Blue Chip Stamps. It's a troubling tone that has led me to examine the substantial empirical data that exist with respect to the New York bar in the middle of the twentieth century. It is the tone of the critical (and deeply methodologically flawed) New York Chamber of Commerce Report (the "Wood Report") ${ }^{11}$ that served as the argument in favor of the legislation. It is a tone of contempt and suspicion. And while it is impossible for me to prove causation directly, since there is no smoking gun that reveals antisemitism as a driving cause of the statute, the circumstantial evidence demonstrates that this in fact is the case.

Interesting as an historical matter, you might say, and not surprising either. But we're past that now. Antisemitism in the bar, while to some extent still extant, is mostly ancient history. We can evaluate these and other restrictions on stockholder suits purely on a policy basis. You might say that. But you'd be wrong, because we don't. The pervasive negative attitude towards stockholder suits, whether derivative or class action, continues irrationally to poison our attitudes towards plaintiffs' lawyers and their role in our corporate system. To read the legislative history of a statute like the 1995 Act is to see that its passage was a function of attitude and lobbying - no significant empirical data is cited to support its conclusions. ${ }^{12}$ And its burden fell unequally, almost exclusively on eastern, urban Jewish lawyers.

As recent events from Enron to WorldCom continue to show, the trust in corporate

optimistic, even in their pessimism, is borne out by the statistics discussed in Part II.

${ }^{11}$ The Wood Report and its failings are discussed infra at _- ..

${ }^{12}$ Hearings Before the Subcommittee on Securities of the Committee On BANKING, Housing, AND Urban AfFaIRS, United States Senate, S. Hrg. 104-157, March 2, 22, and April 6, 1995. (the legislative history of the 1995 Act is rather long on rhetoric and virtually devoid of any empirical evidence with respect to the actual costs of 
America and the concomitant distrust of the corporate plaintiffs' bar that are implicit in the rules are unjustifiable. These attitudes and the laws they engender are the relics of antisemitism, and they are attitudes which have increasingly led courts and legislatures to let corporate managers off the hook. Even modern finance theory, upon which I'll briefly touch in Part I, illogically and inconsistently fails to treat stockholder suits in the same manner as other nonsystematic risks. Recognizing this should lead us to rethink our attitudes toward stockholder litigation and the laws and policies with which we regulate it. It should make us more attentive to the benefits of this litigation, as well as the recognized costs it imposes, and lead to empirical work evaluating the actual effect that stockholder litigation has on our corporate wealth. Most of all, it should make us stop to examine our attitudes and test them against the world as we know it, not against a world tainted with racism and bigotry.

In Part I, I will take a few pages to show how portfolio theory logically ought to make us relatively unconcerned with stockholder suits, a concern that is so great that it amounted to a virtual witch-hunt (including a congressional override of President Clinton's veto) in Congress' passage of the 1995 Act. In Part II, I will describe the structure of the New York bar from the 1930s through the 1960s, drawing on the rich empirical and sociological evidence available. Part III will examine the law restricting stockholder suits and analyze and criticize its contemporaneous justification. In so doing, I will connect this law to the data in Part II in order to demonstrate circumstantially (which is the only way one can demonstrate such things) the original and persistent antisemitic roots of the doctrine. I will conclude by linking this history to the 1995 Act. I want to be clear that at no point in this article will I analyze the wisdom of the restrictive stockholder suits - it certainly doesn't examine the benefits.) 
policies themselves - that has been amply done by others. My argument is more narrow, and at the same time more broad. It is, in short, that whenever we confront issues regarding stockholder litigation, as Congress did in 1995, we must do so aware of the fact that our overwhelmingly negative attitude towards such lawsuits is rooted in an ugly legacy of antisemitism, an understanding that should make us more cautious in restricting stockholder litigation and more attentive to hard, empirical data.

\section{Finance Theory Supports Stockholder Litigation For the Same Reasons it Supports}

\section{Diversified Portfolios}

I said I wasn't going to debate the merits of restrictions on stockholder suits, and I'm not. But I do want to start by using modern finance theory to demonstrate the irrationality of the opposition (or at least to demonstrate the purely ideological nature of the opposition) to stockholder litigation, an irrationality (or ideology) that lurks in that most rational of disciplines. Modern finance theory tells us (as Enron pensioners evidently learned the hard way) that the best investment strategy for any investor, and the best way for an investor to protect herself, is to diversify her portfolio. Holding different baskets of securities instead of putting your eggs all in one means that if one of your portfolio corporations does poorly, it will likely be offset by superior performance by another. Or, to shift metaphors, if you bet the farm and lose, you lose the farm. So instead of betting the farm, you bet a larger number of truck gardens.

So powerful is this theory that it actually has served as the basis for relaxing managerial fiduciary duties. Why should we protect investors (and in the process perhaps stifle valuable risktaking) when investors can protect themselves, or so the argument goes? Of course courts recognize that their laxity not only allows for greater risk-taking but provides greater latitude for 
misconduct, but as long as misconduct isn't the order of the day, a little unredressed misconduct won't hurt the investor with a well-diversified portfolio. ${ }^{13}$

There is something to commend this approach. In my view, there is more to criticize. But that's beside the point. The relevance of the point to my argument becomes clear when you look at the arguments of those who advocate diluting managerial duties and restricting stockholder suits.

Their argument is that meretricious stockholder suits (which on this view is the vast majority of them) interfere with business and sometimes cost the stockholders large sums of money in settlement payments and legal fees just to get rid of vexatious litigation. ${ }^{14}$ (Of course the assumption that most stockholder suits are meretricious is based on the very prejudice we'll be tracing throughout this article.) Let's assume that at least some substantial number of these suits are without real merit, or of trivial value. If there is any value to stockholder litigation, and there clearly is, as the sole legal means of enforcing internal corporate governance and as a valuable supplement to limited federal resources in enforcing the securities laws, then the fact that some individual corporations may be unfairly harmed is just the other side of portfolio theory, at least from a utilitarian standpoint. That is to say, it is well recognized that stockholder plaintiffs and their lawyers supplement the very limited enforcement resources of the Securities and Exchange Commission in the role of a kind of private attorney general. And this does have real benefit because, left to the Commission alone, much wrongdoing would go unredressed, and the very knowledge that the Commission was the only enforcement authority would create an atmosphere in

${ }^{13}$ Joy v. North, 692 F. 2d 880 (2d Cir. 1982)

${ }^{14}$ Derivative litigation, on which this section focuses, has, due to various statutory and judicial restrictions, virtually faded out of existence. Roberta Romano, The Shareholder Suit: Litigation Without Evolution?, in THE FOUNDATION OF CORPORATE LAW, Roberta Romano, ed. (1993) 170, 172 (shareholder suits are rare). 
which potential wrongdoers could make cost -benefit decisions based upon the (unlikely) probability of getting caught. ${ }^{15}$ Vigorous stockholder litigation helps to keep corporate managers, and our entire corporate capitalist system, honest.

If this is true (and I think pretty much everyone would accept it as true on some level), then the losses incurred by the wrongly- sued corporation (including money paid both in legitimate settlements and pay-offs) are made up for by the diminution in fraud and bad conduct caused by a more potent enforcement regime in which stockholder suits are more easily brought. In other words, an individual corporation (like an individual' s investment in a particular corporation) might suffer, but overall social welfare is higher because corporate conduct is kept at a higher level. It also stands to reason that if corporate conduct overall were lowered, stock prices would generally be lower to discount for the greater likelihood that corporate managers would misbehave, and thus produce a deadweight loss. ${ }^{16}$ So, despite the fact that it has been used only to restrict managerial duties and stockholder litigation, portfolio theory actually justifies a vigorous private enforcement regime with the same power it does the relaxation of managerial duties

Portfolio theory, applied directly, ought to be dismissive of the losses that corporate stockholders suffer due to groundless litigation, at least until those losses exceed the value of enforcement. In light of the fact that Enron alone, in the space of a couple of months, lost approximately $\$ 60$ billion in market capitalization (shareholder value) ${ }^{17}$, and in light of the further

\footnotetext{
${ }^{15}$ One only has to look at recent news to see the truth of this remark.

${ }^{16}$ Anyone who doubts this need only look at the stock performance of corporations that have not been the subject of scandal over the last six months. The market's huge "dishonesty discount" seems to prove the point.

${ }^{17}$ While the loss is dramatic, I should of course note that were Enron's financials accurate in the first place, that level of market valuation would never have been attained.
} 
dramatic stock price drops occurring through July 2002 (the time of this writing) due to corporations revisiting their financial statements (which is another way of saying that they are correcting their frauds or at least their overreaching), it does seem that there would have to be an extraordinarily large number of meretricious stockholder suits with very large settlements (usually not the case) in order to lead to the conclusion that stockholder suits ought, as an objective matter, to be severely limited. And if this is the case, then portfolio theory tells us that a well-diversified stockholder should suffer no greater harm from a portfolio company's settlement of an unjustified suit than she should from managerial mismanagement and theft. ${ }^{18}$ The argument seems so obvious as to be almost not worth making. But nobody has made it.

Why not? Why wasn't this as obvious to the scholars applying portfolio theory to argue in favor of deregulation as were the virtues of a diversified portfolio? Among a number of possible reasons is that we remain blinded by the prejudice against stockholder plaintiffs and their lawyers sown in the 1930s and '40s and embedded in the earlier restrictions on stockholder litigation and its reasoning. We don't see it because we have internalized an ideology arising from bigotry and prejudice. ${ }^{19}$ Once we recognize this, we can perhaps more objectively balance the value of stockholder litigation with the desire to discourage meretricious lawsuits.

Having seen, as a theoretical matter, the obvious financial merit of stockholder litigation to a vigorous market, I will now turn to the central point of this Article, the very reason why we fail to

\footnotetext{
${ }^{18}$ The argument assumes, as I stated earlier, that the benefits of stockholder suits exceed the costs, including the costs of frivolous or strike suits. To my knowledge, nobody has ever designed a method for testing this proposition (nor one to the contrary I might add).

${ }^{19}$ In support of this observation I will have occasion, infra, to discuss the very interesting distinction between prejudice and embedded stereotypes explored by Jody Armour, Stereotypical Prejudice: Helping Legal Decisionmakers Breach the Prejudice Habit, 83 Cal. L. Rev. 733 (1995).
} 
see the merit of stockholder suits.

\section{Jews Without Money ${ }^{20}$}

In 2002 it might be hard to imagine a time in America not only when antisemitism was widespread and virulent but, given the singular success of Jews in America, it may be even harder to imagine a time when the vast majority of American Jews lived in dire, grinding poverty, when substantial numbers of children were orphaned or had only one parent, when children not yet teenagers worked twelve hour days or more in horrible sweatshop conditions, when overcrowded and dangerous tenements and the unbearable stench of the Lower East Side of New York made it difficult for parents to imagine that their children or grandchildren would inhabit executive suites, Wall Street law firms, or Park Avenue medical offices; that they would acquire high political position, and so many other fruits of the American dream. But this was the condition of the average American Jew in the period of highest immigration from central and eastern Europe, 1880 to 1920 , and for some time after. ${ }^{21}$

At the same time, there was a Jewish elite in America that had begun to establish itself in the 1840s and was firmly ensconced in the highest reaches of business and banking, and even politics, by the beginning of the flood of eastern migration. ${ }^{22}$ This group, with names that still adorn our financial and cultural institutions like Lehman, Lewisohn, Schiff, Goldman,

${ }^{20}$ The heading is the title of Michael Gold's 1929 autobiographical novel, which depicts the extreme poverty and difficult living and social conditions of Jews on the Lower East Side of New York in the first half of the twentieth century. See also Henry Roth, CALL It SLEEP (1924). A classic historical and sociological work is Irving Howe, World OF Our FATHERS (1976). See also Howard Sacher, A History OF THE Jews IN AMERICA.

${ }^{21}$ Howe, supra note

${ }^{22}$ Stephen Birmingham, OuR CROWD: THE GREAT JEWISH FAMILIES OF NEW YORK (1967); Howe, supra note _. Birmingham actually places this migration as beginning in 1837 with the arrival in the United States of Joseph Seligman. 
Guggenheim, Sachs, Kuhn, Loeb, Warburg, Seligman, and many other lesser-known yet still

prominent families, were largely accepted into non-Jewish circles, both professionally and - within limits - socially. ${ }^{23}$ Their origin was Germany, where the Haskalah, or Jewish enlightenment, led by philosophers such as Moses Mendelssohn, encouraged Jews to throw off the trappings of orthodoxy and assimilate into Protestant German society on the debatable grounds of modernity. (Mendelssohn's own son converted to Lutheranism, though his grandson, the famous composer Felix, maintained a Jewish cultural identity.) The elite of this group had little trouble assimilating into Protestant American society, for the cultural norms and practices which separated them were few, and their socio-economic status became quite similar. ${ }^{24}$ Many even intermarried within the Protestant elite, and some even converted. ${ }^{25}$ Most were Republican, at least until the late $1920 \mathrm{~s}^{26}$ It is undeniably true that even this elite class of relatively assimilated Jews were still subjected to some suspicion and hostility, as Edith Wharton novels ${ }^{27}$, the antisemitic ravings of the otherwise

${ }^{23}$ Birmingham describes the social limits rather vividly. Birmingham supra note __.

${ }^{24}$ Birmingham details the origins of many of these families. In a large number of cases, the first generation left the orthodoxy of their parents immediately upon boarding ships for America, although most maintained some (although rapidly diminishing ) degree of Jewish observance upon reaching the United States and achieving their early successes. Birmingham, supra note _. My argument is not, therefore, that these early immigrants were children of the Haskalah (in fact many lived in restricted Judengasse and had only limited contact with broader German society, see Robert A. Caro, POWER BROKER (1975), but merely that the environment in which they lived in Germany, including closer contact with the non-Jewish population than in the case of their Eastern coreligionists, were such as to prepare them for rapid assimilation in America. For other studies of this migration and assimilation see Leonard Dinnerstein, ANTISEMITISM IN AMERICA (1994); Howe, supra note

${ }^{25}$ Birmingham, supra note

${ }^{26}$ Howe, supra note __ at 361-2. Howe points out that the majority tended to vote Democrat on the local level, but that German Jews tended to remain Republican whereas Eastern Jews overwhelmingly voted Democrat, although not consistently so. Id. at 368.

27 See esp. THE House OF MiRTH (1905). 
brilliant Henry Adams ${ }^{28}$, and the numerous stories of slights told by as accepted a Jew as Bernard Baruch illustrate. ${ }^{29}$ But most were sufficiently accepted to be willing to put the occasional slight aside. $^{30}$

It wasn't until the mass migration of eastern Jews, following the death in 1881 of the relatively liberal Czar Alexander II and the ascension of his son, accompanied by horrific pogroms and the release of pent-up antisemitism among both the Russian elite and the liberated serfs, that American antisemitism on a widescale basis began to manifest itself. Even then, it was largely directed at the new, stranger, immigrants from the east, who had retained their orthodoxy and had been consigned in the Pale of Settlement to dire poverty, immigrants who arrived poor, dirty, bearing the physical trappings of their religion, and speaking the odd patois of Yiddish. Again the story is well known that while their Americanized German brethren eventually provided charity and other forms of help, they too were somewhat repelled by their distant cousins and, in the timeworn tradition of immigrant Jews everywhere, were concerned that these new, impoverished, unassimilated immigrants would embarrass them by association. ${ }^{31}$ "Native" Americans viewed these immigrants with even more suspicion and outright hostility, and even other immigrant groups

28 See, e.g., VI ThE LETTERS OF HENRY AdAMS (J.C. Levenson, Ernest Samuels, Charles Vandersee, Viola Hopkins Winner, eds., 1988), 301, 369, 390.

${ }^{29}$ Howe, supra note __. The most notorious slight of the era was the refusal of the Grand Union Hotel in Saratoga Springs to admit Joseph Seligman in 1877, by which point he was considered a banker of reputation only below that of J. P. Morgan and was an intimate of and advisor to President Grant. Birmingham, supra note __ at 16065.

${ }^{30}$ Indeed when they did not, their resistance could cause enormous social upheaval both within the German Jewish community and the larger elite American society, as Joseph Seligman's reaction to his exclusion from the Grand Union Hotel in Saratoga Springs illustrates. Birmingham, supra note

${ }^{31}$ Howe, supra note _. 
like Italians and Irish - subjected to prejudice themselves - were concerned that these Jews, who would work for virtually anything, would take their jobs, which led to violence (particularly among Irish immigrants and their descendants) toward Jews. ${ }^{32}$

This is the situation that persisted largely up to the 1920s and grew with increasing fervor until its peak - oddly enough - during World War II, a period to which Leonard Dinnerstein refers as the "high tide" of antisemitism in America. ${ }^{33}$ This of course was the period during which section 61-b was conceived and enacted. It was a time when the America First Committee, formed to keep the United States out of the war, attracted as its leaders Henry Ford and Father Coughlin, men who previously had established famously antisemitic reputations. Leaders of this committee insisted that the Roosevelts and "90 percent of the New Dealers" were Jewish, that Jews were in control of the federal government, and that Hollywood producers (who were of course Jewish) were making movies designed to lead America into war (and which accusation led to a Senate investigation into Hollywood). It was a time when Charles Lindbergh, fresh from receiving a medal from his hero, Hitler, spoke against the Jews who controlled the press, the media, Hollywood, and the federal government. While Lindbergh was so heavily criticized that the America First Committee virtually disappeared, antisemitism during this period continued to

32 See e.g. Dinnerstein, supra note _ at 121 (describing Irish American support for the violent and violently antisemitic Christian Front in 1939).

${ }^{33}$ Dinnerstein, supra note _ at 128 . It is worth noting that while statistics show a peak of antisemitism during this period, there was enormous antisemitism in earlier decades. This earlier antisemitism seems more violent and more populist in nature, led by demagogues like Father Coughlin and Henry Ford's Dearborn Independent. The class of WASP about which I am speaking would never have engaged in this crude, largely lower and middle class, form of antisemitism. For an interesting story of the deep racial antisemitism that ran through the American military in the years after World War I see Joseph W. Bendersky, THE "JEWISH THREAT": ANTI-SEMITIC POLITICS OF THE U.S. ARMY (2000). 
increase. ${ }^{34}$ Dinnerstein quotes Jewish actor Kirk Douglas, who easily "passed", as saying during this period: "the things that in their nightmares Jews speculate non-Jews say ... I found out they do." 35

Regularly kept polling data demonstrate increasing antisemitism during this period. ${ }^{36}$ In May 1938, 36 percent of respondents agreed that Jews had too much power in America; by 1945 (when Hitler had essentially annihilated European Jewry and the Jewish migration to America had long been stemmed by the federal government) that number had risen to 58 percent. ${ }^{37}$ When Charles Lindbergh made his famous Des Moines speech in 1941 on behalf of the America First Committee, he named three groups he believed were drawing America into the war; Jews, the Roosevelt administration, and pro-British groups. In a survey conducted later that year, $40 \%$ remembered the accusation against Jews compared with $31 \%$ as to the Roosevelt administration and $21 \%$ as to pro-British groups. ${ }^{38}$ This leaves the distinct impression that antisemitism had by then become a significant part of the American consciousness. And despite this fairly widespread belief that Jews were agitating to involve America in the war, once the war had begun at least onethird of the American population believed that Jews were less willing to serve in the armed forces

\footnotetext{
${ }^{34}$ Dinnerstein, supra note __ at 129.

${ }^{35} I d$. at 131 .

36 See the rich empirical data contained in JEWS IN THE MIND OF AMERICA (Charles Herbert Stember, et. Al, eds. 1966), esp. Chapter 5 (dealing with the World War II era).
}

${ }^{37}$ Id. See also Stember, supra note _- at 121-2.

${ }^{38}$ Stember, supra note _ at 114. 
and less patriotic than even German and Japanese Americans. ${ }^{39}$ In June 1944, 24 percent of survey respondents identified Jews as the greatest menace to Americans, with only 9 percent identifying Japanese and 6 percent identifying Germans - and this almost a full year before the European war had ended and during a time when Jewry had virtually been wiped out in Europe. ${ }^{40}$

Antisemitism simply was pervasive throughout America during this era, the era of the Wood Report. Dinnerstein notes a 1942 poll asking high school students who would be their last choice as roommates. The only double-digit negatives were, unsurprisingly, African -Americans at $78 \%$, and Jews at $45 \%$. A similar report by Fortune contemporaneously with this study asked factory workers who they would least like to have move into their neighborhoods and this time African-Americans and Jews were joined by the Chinese (who interestingly scored only $9 \%$ on the student survey) with $72 \%, 42 \%$ and $28 \%$, respectively. ${ }^{41}$ Finally, a poll asking the respondent whether he or she had heard any negative comments of Jews during the preceding six months led to 46 percent affirmative and 52 percent negative responses in 1940, growing steadily to 64 percent affirmative and 34 percent negative in 1946, a year after the war ended and the reality of the Holocaust had been widely reported. ${ }^{42}$

\footnotetext{
${ }^{39}$ Id. At 116-7.
}

${ }^{40} \mathrm{Id}$. Two years earlier, the results were almost inverse in direction, if not in magnitude, with $24 \%$ identifying Japanese, $18 \%$ identifying Germans, and a still significant $15 \%$ identifying Jews. Id. It's worth noting that since all of this polling data explores peoples' self-professed attitudes, there might be an underreporting bias in antisemitic attitudes. Given the general public acceptance of antisemitism during this period it is hard to imagine that there is an overreporting bias.

${ }^{41} I d$.

${ }^{42} I d$. at 132. The horror stories of antisemitism during this era, from citizens' groups organized to criticize Jews to Coughlinites to the deep antisemitism embedded in textbooks as well as in the military, from ordinary soldiers threatening their Jewish colleagues to government training manuals, are sufficient to fill volumes. It seems adequate to establish the environment in which the Wood Report was drafted to provide the evidence in the text and refer the 
Nativism and general anti-immigrant sentiment, as well as class and economic conflict, added to the cruder and more virulent forms of antisemitism. But despite its popular peak in the 1940s, it had already become deeply embedded in the consciousness of the eastern, urban, Protestant elite, that very group that had accepted the German Jews into their numbers. As Digby Baltzell so convincingly reports, it was the relatively quick transformation of mass Jewish poverty into Jewish economic success that led antisemitic attitudes within the Protestant elite to become more ingrained. ${ }^{43}$ From their hegemony in the 1920s, referred to by Baltzell as "The Anglo-Saxon Decade", by the 1940s WASPS had already begun to withdraw significantly from the public arena, defeated by the liberalism of the New Deal, their loss of their power in Washington, and the booming economic success of immigrant groups. ${ }^{44}$ What had principally been for them a matter of class (although I don't mean for a moment to dismiss their latent - and sometimes blatant - racial antisemitism $)^{45}$, now became a matter of caste, as their increasing loss of power to Jews led to their

interested reader to other sources. See e.g., Steven Alan Carr, Hollywood AND ANTISEMITISM: A CULTURAL HISTORY UP TO WORLD WAR II (2001), ANTISEMITISM IN AMERICA TODAY: OUTSPOKEN EXPERTS EXPLODE THE Myths (Jerome A. Chanes, ed., 1995), Roberts S. Wistrich, ANTISEMITISM: ThE LONGEST HATRED (1991).

${ }^{43}$ E. Digby Baltzell, The Protestant Establishment: Aristocracy ANd CASTE In AMERICA (1964). This book, in which Baltzell, who is credited (evidently wrongly) with coining the acronym "WASP", spends more time on antisemitism than any other social attitude of the WASP elite, arguing that antisemitism largely defined the WASP caste. See Eric Pace, E. Digby Baltzell Dies at 80; Studied WASPs; The New York Times, August 20, 1996, Sec. B, p. 6 (in which Baltzell's widow is quoted as saying that he was wrongly credited with coining the term).

${ }^{44}$ Such withdrawal in the face of adversity characterized the predecessors of the WASP caste in the Gilded Age, as so wonderfully detailed in the whinings of Henry Adams. See THE EduCATION OF HENRY AdAMS (Ernest Samuels, ed.).; Baltzell, supra note _ at 112-13.

${ }^{45}$ One might be tempted to think that the story I tell is one based on class rather than antisemitism. I shall do my best to demonstrate otherwise infra note _ . As to the racist aspects of antisemitism, it does appear that the easier social acceptance of German Jews in contrast to Eastern European Jews supports antisemitism as a hybrid form of racism. For an argument suggesting the grounding of at least some strain of American antisemitism in racism, see Jack Wartheimer, Antisemitism in the United States: A Historical Perspective, in ANTISEMITISM IN AMERICA TODAY, supra note _ at 33, 46. Bendersky, supra note _, comes down clearly on the side of biology and race in explaining military antisemitism, with frightening echoes of Nazi ideology. 
retreat into private and exclusive clubs, resorts, suburban enclaves like Bronxville and Tuxedo Park, and the closed urban society of the Upper East Side. In so doing, they ultimately relinquished the role of ruling aristocracy for the more comfortable and less challenging role of social elite. As they saw their power wane, they - the heirs of the colleagues of nineteenth century German Jewish financiers - fully internalized the antisemitic stance that had become pervasive throughout America. ${ }^{46}$ Clubs and exclusive neighborhoods, not to mention exclusive social circles, provided safety and affirmation. As in the face of the Progressive onslaught during the Gilded Age, the “'decent people'”, as Baltzell quotes Edith Wharton as saying, "'fell back on sport and culture. "'47

Yet the new class of immigrant Jews was improving its lot through hard work and education. In fact this was precisely why antisemitism among the Protestant elite became so pervasive. Certain kinds of businesses remained relatively open, ${ }^{48}$ perhaps because commercial transactions didn't require the sustained contact that other kinds of businesses requiring more social interaction did. But the professions were different, and the state of the bar, especially in New York, is illustrative of the severe limitations on Jewish advancement within the elite ranks of the legal profession, limitations which persisted at least through the 1960s. Jews were excluded from much

${ }^{46}$ Baltzell, supra note __; Dinnerstein, supra note _ a at Chapter 7.

It's interesting to note some of the parallels between the behavior of the WASP aristocracy and nonslaveholding Southern whites in the ante-bellum period. In each case, the existence of a lower class facilitated the maintenance of caste, regardless of personal or individual economic achievement.

${ }^{47}$ Baltzell, supra note _ at 113.

48 Principally in the soft-goods and retail trades, and of course entertainment. Heavy manufacturing, commercial banking, finance, transportation, and insurance were still the province of the WASP elite. Baltzell, supra note _ at 207-8. 
of industry, engineering and, for the most part, medicine, and while not from law, certainly from the elite corporate bar. Instead, they turned to other forms of legal practice, including challenging those corporations through derivative litigation, in order to make a living. In so doing, they refused quietly to accept their second class status and strived for economic success in the only ways available to them. In so doing, they hit the Protestant elite, which controlled American industry and the corporate bar, exactly where it lived.

In presenting the evidence, I will rely as nearly as possible on the extant statistical data. Although there is a plethora of narrative description (on which I must and will rely to some extent), it is far too easy in a study like this to rely upon horror stories and rhetorical flourishes to make the point. Thus, while I might be dry, I shall try to rely on available data rather than normative rhetoric.

One last point. Discrimination between elite (read Protestant) and other lawyers hardly was something new. In fact the Association of the Bar of the City of New York, founded in 1870, was itself an attempt to stratify the bar, and every president of the ABCNY from 1870 to 1920 was listed in the New York Social Register. ${ }^{49}$ Its Grievance Committee spent disproportionate amounts of time investigating ethnic lawyers who typically were sole practitioners rather than corporate lawyers who were members of firms. The American Bar Association was little better. J. Clay Smith, Jr., in his study of Black lawyers, quotes one "influential" ABA member in the 1920's as noting that "the legal profession was a means by which Jews, immigrants, and city-dwellers might undermine the American way of life."50 Thus, the ABA attempted to shut down law schools

${ }^{49}$ Lawrence Fleischer, Association of the Bar of the City of New York: 125 Years 1870-1995; The City Bar: Then and Now, New York Law Journal, September 11, 1995, p. S1.

${ }^{50}$ J. Clay Smith, Jr., EMANCIPATION: THE MAKING OF THE BLACK LAWYER, 1844-1944 (1993); Robert Stevens, LAW SCHOOL: LEGAL EDUCATION IN AMERICA FROM THE 1850S TO THE 1980S (1983) 100-01; 184; 
catering to these three groups whom, as we will see, in New York were all one and the same: Jews.

And while in the very early years, the "dregs" of the bar consisted of a more varied group of minorities (some Irish lawyers as well as Jews, who were centered at least in part around the Tammany Hall machine), by 1944 the demographics of the bar, but not the attitude of the elites, significantly had changed.

Concrete evidence of antisemitism appears in a report (the "Report") based on a study of the Conference on Jewish Relations, led by Simon Rifkind. (Rifkind was later to become a name partner of one of New York's premier law firms, a firm that included, among others, Lloyd Garrison, dean of the University of Wisconsin Law School and grandson of the great abolitionist William Lloyd Garrison, and adopted principles of racial and ethnic equality as well as public service. $)^{51}$ The Report describes in excruciating empirical detail the plight of Jewish lawyers in New York in the 1930s. ${ }^{52}$ It begins by quoting one New York Jewish lawyer as describing the practice of law as "'a dignified road to starvation."”53 And based on the data revealed in the Report, this was far more the rule for Jewish lawyers than the exception. But my interest is not in disparate income. It is in the evidence of discrimination that led to that disparity.

Auerbach, supra note _-

${ }^{51}$ Melvin M. Fagen, The Status of Jewish Lawyers IN New York City, 1 Jewish Soc. Stud. 73 (1939)

Paul Weiss traces its roots to 1875 but took its modern form in 1946. Rifkind joined the firm in 1950. In the interest of full disclosure, I spent several happy years as an associate at the firm, Paul Weiss Rifkind Wharton and Garrison.

${ }^{52}$ Fagen, supra note __. Further evidence of bar stratification and its antisemitic basis is provided in Richard L. Abel, AMERICAN LAWYERS (1989) at 85-87, and Edward A. Purcell, Jr., LiTIGATION AND INEQUALITY: FEDERAL DIVERSITY JURISDICTION IN INDUSTRIAL AMERICA, 1870-1958 (1992), at 150-154 (discussing the somewhat different but sociologically related development of the plaintiffs' personal injury bar).

${ }^{53}$ Fagen, supra note __ at 74. 
Let's begin with the demographics of the bar. The Report estimated that approximately 22,000 lawyers were practicing in all five boroughs in 1937, of whom 11,400 were Jewish. Of the $11,400,9,467$ practiced in Manhattan. ${ }^{54}$ At that time, Jews constituted roughly $28 \%$ of the population of New York City. ${ }^{55}$ Clearly the proportion of Jewish lawyers was grossly disproportionate to the number of Jews in the population. ${ }^{56}$

The first interesting question is where these lawyers were educated, since the Report convincingly concludes that an important determinant of income and status within the bar was the law school attended. ${ }^{57}$ Fully $66.8 \%$ of Jewish lawyers who had attended law school graduated either from Brooklyn (25.8\%), New York University (22.7\%, and which was at least 45 to 50 years away from joining the ranks of the elite), New York Law School (12.1\%), St. John's Law School (10.7\%), and Fordham (6.2\%), none of which even remotely numbered among the elite law schools in the nation. The only elite school attended by New York Jewish lawyers in any

\footnotetext{
${ }^{54}$ The identification of lawyers in New York was based upon United States census data. The identification of Jewish lawyers was done by including those lawyers who listed themselves as belonging to Jewish organizations or contributing to Jewish charities, as well as by a search through Martindale-Hubbell for lawyers with "obviously" Jewish names. Those lawyers with "obviously" non-Jewish names were excluded, and an ambiguous group consisting of about 3,000 lawyers was further reduced as much as possible by discussion with lawyers familiar with those in question. Fagen concedes the imprecision of this methodology, supra note _ at 75, and I, whose decidedly nonJewish name was bestowed unwillingly upon my family by an insistent customs official, am particularly sensitive to this flaw. Nonetheless, based on its methodology, the survey seems more likely to have underestimated the number of Jewish lawyers than overestimated them.

${ }^{55}$ The population of New York City in 1940 was 7,454,995. www.census.gov/population/documentation/twps0027/tab17.txt.

${ }^{56}$ For an explanation of the sources of population data, see Appendix A. I have no effective means of counting commuting lawyers and their ethnicity living in suburbs like Bronxville, Greenwich, and Scarsdale. It is well-known, however, that Jews had not significantly migrated to the suburbs at this time and that suburbs like those mentioned did not welcome Jews. In the case of Bronxville, it positively excluded them. For evidence that Jewish migration to the suburbs significantly began at the end of World War II see William E. Nelson, THE LEGALIST REFORMATION: LAW, POLITICS, AND IDEOLOGY IN NEW YORK, 1920-1980 (2001).

${ }^{57}$ Fagen, supra note _ at 80 . All data contained in the text are also presented in tabular form as appendices
} 
meaningful numbers was Columbia (11\%), somewhat of an oddity in light of that university's own antisemitic tradition. ${ }^{58}$

The Report identifies the principal reason for Jewish attendance at lower-level law schools in the fact that they had night programs and tuition was cheaper ${ }^{59}$, two factors highly important to students from relatively poor families. It never mentions antisemitism as a factor at all. Auerbach, Howe, and Baltzell, however, all clearly identify antisemitism as a major factor limiting Jewish attendance at elite universities. ${ }^{60}$

Let's see how this educational disadvantage led to a bar structure highly disadvantageous to Jews. In 1937, few Jewish lawyers were corporate practitioners, by far the most lucrative practice area. Only $11 \%$ of Jewish lawyers reported having a corporate practice, with a large plurality dependent upon small merchants (35.28\%), and "general" practice $(22.15 \%)$. Sixty percent of Jewish lawyers reported being sole practitioners, the lowest income level group with a 1937 median of $\$ 1,874(\$ 24,105) .{ }^{61}$ Only $6 \%$ reported being the head of a firm (with a median

to this article.

${ }^{58}$ Fagen, supra note __ at 82. Columbia was the first elite university to restrict Jewish admissions. John Higham, Social Discrimination Against Jews in America, 1830-1930, in V THE JEWISH EXPERIENCE IN AMERICA: AT Home In America (Abraham J. Karp, ed. 1969) 349, 369; Marcia Graham Synnott, Anti-Semitism and American Universities: Did Quotas Follow the Jews?, in 6 AMERICAN JEWISH HISTORY (Jeffrey Gurock, ed., 1998), 473, 47980, 499; William E. Nelson, ThE LEGALIST REFORMATION: LAW, POLITICS, AND IDEOLOGY IN NEW YORK, 1920-1980 $152(2001)$.

${ }^{59}$ Fagen, supra note __ at 81.

60 Jerold Auerbach, UNEQUAL JusTICE, 126-7 (1975); Baltzell, supra note __ at 129-35; 209-12; Howe, supra note __ at 411-12. Auerbach, Baltzell, and Howe all were writing after the fact. It may be that part of the reason for the reticence of the Report to identify overt antisemitism as a cause is a tradition of Jewish-American fear of stirring even more antisemitism by claiming the existence of antisemitism. See generally Alan Dershowitz, CHUTZPAH (1991).

${ }^{61}$ The numbers following each mean in parenthesis gives the immediately preceding amount in 2002 dollars based on the U.S. Department of Labor on-line inflation adjuster. http://www.bls.gov/cpi/home.htm\#data. I have used 
income of $\$ 8,879(\$ 114,213)), 15 \%$ reported being a member of a firm (with a median income of $\$ 4,137(\$ 53,215)$ ) and $14 \%$ reported working as an employee of a firm (with a median income of $\$ 4,137(\$ 53,215))$. The median income for Jewish lawyers as a group was $\$ 2,426(\$ 31,206)$, compared with $\$ 2,990(\$ 38,461)$ for all New York lawyers. Throughout their careers, New York lawyers as a group ranged from $21 \%$ as firm members (with five to 10 years experience), to $35.34 \%$ as firm members (with 17-23 years of experience), and with comparable proportions (in the mid-30\% range) for lawyers throughout their careers. As heads of offices, the most lucrative practice situation, lawyers in the general New York population ranged from $14.38 \%$ for 5-10 years of experience up to a high of $33.38 \%$ for $24-34$ years of experience. In their early years of practice, New York lawyers as a whole were employed overwhelmingly more than Jews in firms, $39.27 \%$ to 9.74\% from 4 years or less, diminishing to $22.16 \%$ versus $11.82 \%, 11.27 \%$ to $19.93 \%$, and reaching a situational reversal of $3.02 \%$ to $29.16 \%$ for 35 years of practice and more. ${ }^{62}$ Looking at the numbers, the clear explanation for the increase of Jewish firm employees and the decrease of employee-lawyers in the general population can be found in the substantial increase in the general population of lawyers who became members of the firms by which they were employed, or headed their own firms, numbers which remained relatively insignificant for Jewish lawyers. The vast majority of Jewish lawyers did not have firm jobs early in their careers, which of course is the time when the track to partnership is established, and this most likely accounts for their small proportion of membership in firms. While they may have been more accepted as firm employees when they became more experienced lawyers, they were clearly not accepted as firm members.

the same source of conversion throughout this article.

\footnotetext{
${ }^{62}$ Fagen, supra at note __ at 86-92, 101-103.
} 
The conclusion that the vast majority of Jewish lawyers were marginalized in the New York bar only seven years before the adoption of Section 61-b is inescapable. ${ }^{63}$ Nor had the situation changed in any meaningful way by 1960, the next year for which significant data are available and a period not long before the Supreme Court began to impose substantial restrictions on securities litigation. The data come from a report drafted by Columbia sociologist Jerome Carlin (the "Carlin Report"), examining the "social conditions of moral integrity in the legal profession." ${ }^{64}$ The Carlin Report, despite its broad ambition, limited its inquiry to the New York bar as the nation's most significant. Carlin's conclusions that ethical behavior is a function of status within the bar and the determining nature of one's practice are important, and will become relevant later in this section. For now, I want simply to concentrate on the data that more or less parallel Fagen's 1939 study.

In 1960 (the focal year of Carlin's data), there were approximately 26,000 lawyers in Manhattan and the Bronx, of whom 17,000 were active private practitioners. Seventy percent of these lawyers reported receiving at least $50 \%$ of their income from business practice, but the vast majority of these represented small businessmen and closely held corporations. Only $20 \%$ reported that most of their work involved representing large corporations. ${ }^{65}$ In describing the hierarchical structure of the New York bar, Carlin notes that "the firm is the significant unit for the system of

\footnotetext{
${ }^{63}$ Stevens, supra note __ at 146. ("In the 1930s to the 1940 s, Jewish students were heavily channeled into government service, teaching, and the non-elite or predominantly Jewish law firms. There was still a hint of antisemitism among the large firms in the 1960's.") Indeed, it persisted into at least the early 1980s and may well persist today. See infra notes _ and _.

${ }^{64}$ Jerome E. Carlin, LAwYers' Ethics; A Survey of THE New York CiTy BAR (1966)(quote at xxviii).

${ }^{65}$ Carlin, supra note _- at 11-13.
} 
social stratification of the bar." ${ }^{66}$ While 4,300 law offices with from one to 100 lawyers were counted in Manhattan and the Bronx, and more than 50\% of lawyers reported working in firms, only $21 \%$ reported working in firms of 15 or more, a fact which has a great deal of significance for bar hierarchy. ${ }^{67}$

Before linking firm size and the nature of practice with ethnicity, I shall take a brief look at the ethnic composition of the bar in 1960. One interesting change from the 1937 data, which reported that only $68.6 \%$ of Jewish lawyers were native born in contrast to $80.8 \%$ of the bar overall, ${ }^{68}$ is that the Carlin report shows that "almost all" members of the New York bar were native born. More than sixty percent of these were Jewish, in contrast to $18 \%$ Catholic and $18 \%$ Protestant. $^{69}$ Fully $70 \%$ of Jewish lawyers were of eastern European descent (recall the earlier class distinction and difference in social acceptability between German and eastern European Jews). ${ }^{70}$ Thirty-six percent of all lawyers graduated from what Carlin describes as "high quality university law schools."

Where a nascent lawyer attended law school was of critical importance to bar status. In

\footnotetext{
${ }^{66}$ Carlin, supra note _ at 18.

${ }^{67} I d$.

${ }^{68}$ Fagen, supra note_at 79.

${ }^{69}$ Carlin, supra nte _ at $18-19$.

${ }^{70}$ Carlin's data refers to all practicing lawyers, regardless of date of admission to the bar. Breaking down the data further, he notes that the proportion of Catholic lawyers remained constant, the proportion of Jewish lawyers since the Fagen report had declined to $50 \%$ in the mid ' 30 s to mid ' 40 s, then rising and stabilizing at $65 \%$, and the proportion of Protestant lawyers declined from $25 \%$ in the 1920 s to stabilize at $10 \%$ by 1955 . He explains the entry into the bar of significant numbers of Jewish lawyers as caused by the rapid expansion of "mixed law schools," by which he evidently means law schools of lesser quality and characterized at least in part by their offering of night
} programs. Carlin, supra note _ at 20-21. 
fact, Carlin notes that the social status of lawyers really was fixed upon their matriculation into college, beginning a circular trap in which the status of undergraduate institution was dependent upon religion and parental socio-economic status, and the likelihood of admission to elite law school was dependant upon the status of undergraduate institution, with the result that Jewish lawyers whose parents had relatively low socioeconomic status had little chance of attaining elite status in the bar. ${ }^{71}$

The 1960 data bear this out, but they also tell a more troubling story. It seems almost too obvious to state that there was significant discrimination among Jews at the elite colleges and law schools. As to college, $70 \%$ of Protestants of high socio-economic status, $42 \%$ of middle socioeconomic status, and $28 \%$ of low socio-economic status attended Ivy League or similar quality colleges. $^{72}$ By contrast, $34 \%$ of Jews of high socio-economic status, $17 \%$ of middle socioeconomic status, and $9 \%$ of low socio-economic status, attended similar colleges. At the top schools, the relationship between high socio-economic Protestants and Jews is almost inverse. A high socio-economic status Jew was only $6 \%$ more likely to attend a top college than a low socioeconomic Protestant (where the difference was 42 percentage points among Protestants). ${ }^{73}$ To put it differently, a low status Protestant had an almost three in one chance of attending an Ivy League school. For the low status Jew the chances were slightly less than one in ten.

\footnotetext{
${ }^{71}$ Carlin, supra note __ at 22, 28-32.

72 Carlin uses the term "top quality colleges" and provides a category of "other top quality colleges" in his data. He does not define these, but one suspects he means Williams, Amherst, Swarthmore, Haverford, Stanford and the like. As any academic knows, the quality and reputation of colleges is fluid. Rankings didn't exist at the time, at least not in a form I was able to find. See, e.g., Clarence E. Lovejoy, LovEJOY's COLLEGE GUIDE (1961-62).

${ }^{73}$ Carlin, supra note _ at 29. Catholics fared even worse with respect to high-status college admissions, but their presence in the bar was dramatically lower than that of Jews. However, Carlin notes that, adjusting for college and law school attended, Catholics had about the same chance of being in a large firm as Protestant lawyers.
} 
Seventy-seven percent of large firm lawyers attended Ivy League law schools in contrast to only $20 \%$ of small-firm lawyers and sole practitioners. While the disparity between Protestants and Jews attending top law schools diminishes dramatically (though it remains significant) among nascent lawyers attending top quality colleges, the initial disparity in college attendance considerably magnifies the difference. ${ }^{74}$

But it's not just about law school and college. Race played a seemingly independent role in bar status. Only 19\% of Jews with a top education were members of large firms compared with 45\% of Protestants. As Carlin notes, " a Jewish lawyer who achieved high academic standing (that is, was selected for the staff of law review) in an Ivy League school has no better chance of being in a large firm than a Protestant lawyer who did not 'make law review' and who attended a non-Ivy League law school. ${ }^{75,}$

Finally, for our purposes, Carlin demonstrates that there was substantial immobility between strata of the bar throughout a lawyer's career, and that race played an important role in this as well. It should not be surprising by this point to realize that Jewish lawyers had significantly less upward mobility and more downward mobility than Protestant lawyers. One of the important practical results of all of this, which I will discuss further in Part II, is that lawyers at different levels of the bar had very little contact with one another and very little shared professional experience. As one piece of evidence, it's worth noting that the prestigious Association of the Bar
${ }^{74}$ Carlin, supra note __ at 30.

${ }^{75}$ Of course there was substantial self-selection, but this was due to the common knowledge among law faculties and Jewish law students that their chances of jobs at big firms were de minimus. My own father (St. John's Law School 1956, law review editor,\#2 in his class) reports that he and other Jewish students were carefully directed by the dean to those firms that might consider hiring Jewish applicants. See also LAW ProfESSORS TALK, supra note 
of the City of New York was dominated by Protestant, large-firm lawyers, while the more plebeian New York County Lawyers' Association was populated principally by small firm lawyers and sole practitioners (and hence, Jews). ${ }^{76}$

Needless to say, antisemitic discrimination in the bar at least mirrored the problem of antisemitism and racial exclusion in the larger society. ${ }^{77}$ The marginalization of Jews at the lowest levels of the bar (and at the correspondingly lowest income levels), as well as their social exclusion from the circles traveled by large-firm elite Protestant lawyers, sets the stage for the suspicion and hostility that led to the restrictions on stockholder litigation and our attitude towards the corporate plaintiffs' bar. ${ }^{78}$ Let me now turn to describe those restrictions and their historical development.

\section{The Development of Restrictions on Stockholder Litigation}

The restrictions on stockholder litigation in which I'm interested cover two principal areas:

Derivative litigation against corporate officers and directors, and securities fraud litigation, typically brought in the form of class action suits against corporations and their officers and directors. Class actions, which really only developed in the 1960s, are far more technically

${ }^{76}$ Carlin, supra note _ at 36.

${ }^{77}$ Baltzell, supra note _..

78 I point out, as an aside, that such subtle exclusion continues in some Protestant circles today. In 1998 I had occasion to look through the internal directory of one of New York's largest, historically "white shoe", law firms, a firm that prides itself on its international scope. Using the same, admittedly flawed, methodology as Fagan, and giving the benefit of the doubt to names that could either have been Jewish or German (as well as including more innocuous names like Brown and Green which often are Jewish -unless of course the person's first name was clearly non-Jewish like, for example, Winthrop), I found that approximately ten percent of the partners and associates were Jewish. One would expect random hiring for a top New York firm to produce at least 40 percent Jewish lawyers. Seymour Martin Lipset and Earl Raab note that "during the last three decades, Jews [in the United States] have made up. . . 40 percent of partners in the leading law firms in New York and Washington. Seymour Martin Lipset and Earl Raab, JEWS AND THE NEW AMERICAN SCENE (1995), 26-7. (Presumably the number should be higher since not every associate becomes a partner.) Even discounting for the firm's tendency to hire principally from elite law schools, this suggests that there is some discrimination, no matter how subtle, still going on at this firm, or perhaps - to use the mid-century WASP phrase of discouragement - Jews "just wouldn't be comfortable there." 
complex and have much broader application than derivative actions. As a consequence, my main focus is on derivative litigation, although the attitudes towards plaintiffs' lawyers formed in that context transferred to the securities class action context when that became the dominant mode of challenging corporate misbehavior. I've already mentioned one of the earliest forms of restriction on derivative litigation, section 61-b of the New York Business Corporations Law. Before explaining how the restrictions contained in the statute affect plaintiffs, a brief primer on derivative litigation is in order.

The locus of (almost) absolute power in the corporation is the board of directors, a statutorily created body with the function of overseeing the affairs of the corporation. Over time, the board's role has evolved from a more managerial to a more monitoring role (including the very important function of hiring and firing the CEO). In light of the fact that the board's powers are virtually absolute, the law has imposed on directors (and on corporate officers and other employees as well), fiduciary duties to the corporation designed to ensure that those powers are exercised in the corporation's best interest and not for the benefit of corporate insiders or anybody else. In a post-Enron world, it doesn't require much proof to establish (if it ever did) that directors and officers sometimes violate these fiduciary obligations, either by shirking their responsibilities (governed by a doctrine known as the duty of care) or by enriching themselves at the corporation's expense (governed by a doctrine known as the duty of loyalty). It is undisputed that the board is the ultimate voice of the corporation. Hence a dilemma. If the board speaks for the corporation, how likely is it that it will sue itself (or members of the board or corporate officers) in cases in which they violate their fiduciary duties? The answer should be obvious. 
Equity rode to the rescue. ${ }^{79}$ In order to permit meaningful enforcement of these duties, courts created the device of the derivative suit. Put simply, derivative suits permit a stockholder (after making a demand on the board to rectify the situation and having that demand rejected) to bring a suit against the offenders in the name of the corporation. Technically the derivative suit is a two-part action, the first being the stockholder's suit against the corporation to bring action, and the second the corporation's suit (through the stockholder as nominal plaintiff) against the offending officers and directors.

Contemporary law has developed the procedural prerequisites of derivative litigation to the point where it's extremely difficult for a plaintiff ever to get to the merits of the case. But derivative litigation did seem to present a problem. You see, unless a stockholder owned very substantial amounts of stock (and few did), no one stockholder had much of an incentive to sue the directors or officers. Recovery per share was likely to be minimal except in the very rare case of massive wrongdoing, and such amounts as were recovered went to the corporation as the real party in interest. Thus even if a stockholder were to recover, that recovery would be indirect, in the form (theoretically at least) of an increase in share value.

So somebody needed an incentive to sue if the duties were to be enforced at all (since it is a pretty ironclad rule of corporate law that only shareholders have standing to sue to enforce these duties in the first place). The solution was to permit the successful plaintiff's lawyer to recover attorney's fees. Because these cases were taken on a contingent basis (for obvious reasons), the

\footnotetext{
${ }^{79}$ For a history of the development of derivative litigation, from its very primitive roots in the 1810 English case of Adley v. The Whitstable Co., 17 Ves. Jun. 315, 34 Eng. Rep. 122 (Ch. 1810) through the 1950s see the classic, Bert S. Prunty, Jr., The Shareholders 'Derivative Suit: Notes on its Derivation, 32 NYU L. Rev. 980 (1957). See also DeMott, supra note
} 
component of recovery reflecting attorney's fees could be quite substantial, thereby giving lawyers an incentive to take the risk of representing a small stockholder in enforcing fiduciary duties and thus assuring them of having some meaning. ${ }^{80}$

But there, of course, is the rub. For once lawyers had a financial incentive to sue corporations, corporations and their lawyers panicked at the prospect of meretricious litigation, brought solely for the purpose of forcing settlements and enriching lawyers. And, based on our understanding of the demographics of the New York bar (where of course so many of these suits were brought), who do you think the plaintiffs' lawyers in these suits were? Jewish lawyers of course. But that part of our story is for later.

In any event, the prospect of litigation run amok led to the demand for mechanisms to sort out the legitimate lawsuits from the "strike suits." Thus was enacted New York section 61-b. ${ }^{81}$ The reasoning is obvious. If the problem was excessive litigation instigated by people who had no financial interest in the corporation (the lawyers and their shareholding clients) and therefore could not be expected to protect its best interests (quite the contrary), discouraging suit by all but the most significant stockholders ensured that only stockholders who had the interests of the corporation in mind would sue. Thus, you will recall, New York 61-b required stockholders who owned less than $\$ 50,000$ in value (\$507,950 in 2002 dollars) or 5\% of the stock to post security

\footnotetext{
${ }^{80}$ It is unusual for a winning party to collect attorneys' fees in American jurisprudence. The origin of the rule is in $19^{\text {th }}$ century trust law, where beneficiaries of a common fund were held to be responsible for the fees of lawyers whose work benefitted the fund. By 1939, the rule was universal as to derivative suits. Hornstein, Counsel Fees, supra note __ at _.

${ }^{81}$ In light of the general thrust of this article and with no more appropriate place to put this information, it is worth noting that the New York legislature that passed that statute consisted of 51 senators, of whom only 5 had clearly Jewish surnames, and 150 assemblyman, of whom 11 had clearly Jewish surnames. This was an era in which Jews generally did not seek elective office. Howe, supra note __ at _.
} 
for expenses, a costly undertaking in the first place but even more so when one considers that the losing plaintiff would forfeit the bond and be liable for defendant's expenses. Thus the rule virtually ensured that small stockholders would practically be precluded from bringing suit.

Now if you think about it, the rule makes no sense if the purpose is to limit stockholder litigation only to those suits having merit. In the first place, as I already noted, recovery in a derivative action goes to the corporation, not the stockholder. Consequently, a large stockholder would have invested his time and effort in litigation for the purpose of restoring the corporation's value (and only partly and indirectly his individual wealth), thus posing a classic free-rider problem. Why should a large stockholder bother to sue when so much of the benefit would go (indirectly) to the other stockholders anyway? ${ }^{82}$ And why, indeed, when a stockholder with such a large block ought to be in a position to negotiate for a side deal with management on his own? So the ultimate effect of this restriction is to prevent litigation altogether, in the absence of a small stockholder or law firm capable of bearing the financial risk of the litigation. ${ }^{83}$ And that, indeed, should be the end of our story. But it isn't quite the end.

First, although I've described the perceived problem of derivative litigation as being the greed of plaintiffs' lawyers leading them to vex and irritate perfectly innocent (and socially

${ }^{82}$ The personal benefits to the large stockholder might outweigh the cost of bringing suit. More likely, even if the stockholder had a large, illiquid position which might otherwise make suit worthwhile, he could use the power that accompanies the position to pressure management (unless he held a large minority block in a close corporation).

${ }^{83}$ The New York Court of Appeals provided relief to plaintiffs in 1950 in Baker v. McFadden Publications, Inc., 300 N.Y. 325, 90 N.E. $2 \mathrm{~d} 876$ (1950), in which it held that plaintiffs as to whom the statute was invoked and upon whom an order to post security for expenses levied could vacate the order if they were able to solicit sufficient additional stockholders to meet the statute's threshold and act as plaintiffs. According to Stanley Nemzer, a prominent New York plaintiffs' lawyer at the time, this pretty much ended defendants' practice of invoking the statute in order to avoid plaintiffs' circulating serious allegations of wrongdoing about the corporation or its managers among its stockholders. Interview with Stanley Nemzer at the Offices of Wolf Popper, New York City, Friday, April 12, 2002. 
superior) corporate executives with meretricious suits, how big a problem really was derivative litigation? The answer is that it was a not a major problem at all. The Wood Report, my analysis of which follows, would make it seem like a problem of great significance. But a survey of the law review literature from 1900 through 1944 revealed only 44 law review articles, almost all of them student notes, in which derivative litigation even was mentioned. Most of these were focused on the substantive analysis of managerial duties and insider trading, and virtually all of them called for strengthening managerial duties and loosening existing restrictions on derivative litigation. It is worth noting, as an aside, that half of these articles were written after 1929, suggesting that the 1929 Crash and subsequent Depression provoked greater interest in managers' duties. This hardly indicates that derivative litigation was a problem of widespread concern and attention, at least among academics and law students. ${ }^{84}$

Why the concern then, and how was the statute justified? While not a problem of academic interest, perhaps it was a practical problem. Professor Hornstein's tale of a last-minute attack by the release of a secret weapon by the New York Chamber of Commerce is born out by the evidence and appears in the form of the innocently titled: Survey and Report Regarding Stockholders ' Derivative Suits, authored by Franklin S. Wood on behalf of the Special Committee on Corporate Litigation of the Chamber of Commerce of the State of New York. The Report covers 117 pages

\footnotetext{
${ }^{84}$ For a few examples see George T. Washington, Stockholders 'Derivative Suits: The Company's Role, and A Suggestion, 25 Cornell L. Q. 361 (1940) (one of the few articles suggesting reform while expressing the importance of shareholder litigation), Note, Rights of Individual Shareholders against Directors Who Secretly Secure Better Terms for Themselves than for Others in Sale of the Shares of all Members, 20 Cornell L. Q. 101 (1935), Note, The Liability of Directors and Officers for Misrepresentation in the Sale of Securities, 34 column. L. Rev. 1090 (1934); Note, The Statute of Limitations in Stockholders 'Derivative Suits Against Directors, 34 Column. L. Rev. 842 (1939); George D. Hornstein, The Counsel Fee in Stockholders'Derivative Suits, 34 Column. L. Rev. 784 (1939)(noting, interestingly and relevant to my discussion of the Wood Report, that most derivative litigation involved common law and early federal securities law insider trading), id. at 797; Note, The Director of a Corporation as a Fiduciary, 20 Iowa L. Rev. 808 (1935).
} 
of text, along with four substantial appendices, the last of which consists of 18 elaborate charts purportedly detailing every derivative action in New York's First Department (Manhattan and the Bronx), Second Department (Brooklyn, Rockland and Westchester counties), and the United States District Court for the Southern District of New York. It is particularly interesting that the author engaged in such detailed examination of the files, yet limited his report to derivative litigation without any comparative data on litigation in general. It is particularly odd in light of the fact that in 1934 (two years after the beginning of the ten year period examined by the Wood Report), the Judicial Council of the State of New York had begun to compile highly detailed records on all litigation occurring in New York State trial courts, records ignored by Wood ${ }^{85}$ Although contemporaneous critiques of the Wood Report exist, I have analyzed the report independently. ${ }^{86}$

But first a word about the Committee that supported Wood. The Committee consisted of three members besides Wood; Richard Lawrence, Thomas Parkinson, and Arthur Reis. Wood himself was a prominent New York lawyer who, after graduating from Cornell and Cornell Law School, spent several years practicing in Honolulu before returning to New York where he began his own practice until joining what became Hawkins, Delafield \& Wood in 1945. Perhaps the most interesting aspect of Mr. Wood's life for our purposes is not his professional life but the fact that he lived in Bronxville, a town known for its exclusion of Jews, and was a member of the Bronxville Board of Zoning Appeal from 1948 to 1958. Not only as a resident, then, but as a public official, he was undoubtedly quite conscious, and presumably supportive of, the

${ }^{85} 21$ ANNUAl REPORT OF THE JUdicial COUNCIL OF THE STATE OF NEW YorK (1935-44).

${ }^{86}$ Zlinkoff's, supra note _., is the most thorough and thoughtful, and I shall draw upon his critique for one set of data not otherwise readily available. 
"Gentlemen's Agreement" to exclude Jews that existed in Bronxville. ${ }^{87}$ Wood was a member of the University Club (described by Birmingham as "for years, the most steadfastly anti-Jewish club in New York") ${ }^{88}$ as well as several other clubs. ${ }^{89}$

To locate the other committee members within the WASP caste, Lawrence was a member of the Union League of New York and Parkinson a member of the Century Association, both clubs identified by Baltzell as high in the ranks of the WASP aristocracy. ${ }^{90}$ Parkinson was also a member of the Washington, D.C. Cosmos Club, itself highly exclusive (and co-founded by Henry Adams).

Arthur Reis was a Jew, an unsurprising fact given the long historical presence of the token (or "Court") Jew in most non-Jewish establishment organizations, a Jew whose American role it was to lend validity to the decisions of the powerful from "the" Jewish perspective. ${ }^{91}$ Nor is it

${ }^{87}$ Bronxville's discriminatory history is well-known in the New York area. Like the antisemitism implicit in 61-b itself, it is only circumstantially demonstrable (evidently Bronxville builders were not so crude as to include restrictive covenants in their deeds), but those circumstances are rather powerful. See e.g., Harry Gersh, Gentlemen's Agreement in Bronxville, Commentary, February 1959, p.109, Marilynn Wood Hill, Bronxville: From Country Hamlet to Suburb, in Building A Suburban Village: BronXVILle, New YorK, 1898-1998 (Eloise L. Morgan, ed. 1998), pp. 17-19.

While the situation undoubtedly has improved, it is worth noting that one Bronxville resident to whom I spoke said that things were better, telling me that one of the town board members even was "married to a Jew." This kind of remark, no matter how well-meaning, is of course precisely the kind of subconscious racism so well described by Charles Lawrence. Charles R. Lawrence, III, The Id, The Ego, and Equal Protection : Reckoning with Unconscious Racism, 39 Stan. L. Rev. 317 (1987). I confess that I was waiting for my interlocutor to tell me that some of her "best friends were Jewish."

${ }^{88}$ Birmingham, supra note 261.

${ }^{89}$ Like antisemitism itself, Wood evidently was a complex man. He served as plaintiffs' counsel in at least one derivative suit in 1934, and was defense counsel in two others. As plaintiff's counsel, he worked with a Jewish firm. I don't quite know what to make of this other than the assertion I already made; Wood, like antisemitism, was complex.

${ }^{90}$ Baltzell, supra note _ at 368-71.

91 The Court Jew actually is a figure who has existed throughout history. The term comes from the German, 
entirely surprising in light of the fact that Reis was of German Jewish descent which meant, as I

described earlier in the text, that he was likely to have been socially acceptable at one level and that he largely was capable of "passing." And while we know relatively little about him, he likely shared the prejudices of his class with respect to his eastern brethren. ${ }^{92}$ Reis' father, Robert, was a German-born Jew who established Robert Reis \& Company in $1885 .^{93}$ The now defunct Robert Reis \& Company became one of the larger mens' underwear manufacturers. Arthur Reis joined the firm after receiving his A.B. from Columbia in 1903. He eventually succeeded his father as president of the company. ${ }^{94}$ His wife, Claire Raphael Reis, was also from an unusually privileged Jewish background. She was born in 1888 in Brownsville, Texas but was educated in Germany,

in which country the Hofjude, or Court Jew, actually became an official position in the courts of many nobles. The original function of the Court Jew was as a financial advisor, and often a financier as well, since many of the Court Jews were chosen from among the wealthy and because of their excellent business connections. Court Jews often formed family allegiances with other Court Jews which created a kind of upper class among European Jewry, and Court Jews were often subjected to the contempt of other Jews because of their strong desire and often successful attempts to assimilate into mainstream society. At the same time, because of their high positions, Court Jews often were able to, and did, intercede with governing authorities on behalf of the Jewish community. There were no Court Jews as such in America. However, the phrase came to be used as an epithet to describe obsequious Jews who attached themselves to powerful political or business men and who were highly discreet and subordinate with respect to matters of Jewish concern, thus forgoing the opportunity to help other Jews that was utilized by European Court Jews. See generally Ze'ev Glicenstein, The Era of the Court Jew, The Canadian Jewish News, March 14, 2002, www.cjnews.com/pastissues/02/mar14-02/feature3.htm, Philologos, Court Jews: Our Man in Vienna, Forward, February 1, 2002, http://www.forward.com/issues/2002/02.02.01/arts5.html, David E. Lipman, Gates to Jewish Heritage: The Court Jews, http://www.jewishgates.org/history/jewhis/court.stm., FROM COURT JEwS TO THE Rothschilds: ARt, PATronage, Power, 1600-1800 (Vivian B. Mann and Richard I. Cohen, eds 1996), Selma Stern, The Court Jew: A CONTRibution to the history of AbSOlutism in Europe (1985).

92 I have been able to find out relatively little about Reis other than his background and principal activities. Thus I cannot be sure that his attitude towards the class of Jewish lawyers with which we're concerned was negative. The circumstances alone suggest that it was likely that he shared the prejudices of the German-Jewish class, and would have been unlikely to have raised, even if he had seen, the antisemitism implicit in the statute and the Wood Report.

\footnotetext{
${ }^{93}$ Arthur M. Reis, 64, A Manufacturer, N.Y. Times, December 24, 1947 (obituary) at 21.

94 Id.
} 
France and the United States. ${ }^{95}$ Interested in music, she was very active in promoting and teaching classical music in New York City. She became a well-known authority on the subject, received numerous awards, published many articles, and was even invited by Franklin D. Roosevelt to serve on the Committee on the Use of Leisure Time. ${ }^{96}$ Notwithstanding his privileged background and status, it is unlikely that Reis's business would, at an earlier time, have put him at the very highest levels of German-Jewish aristocracy, but he was a member of the Century Club which had supplanted the Harmonie Club at the apex of German-Jewish Society. ${ }^{97}$

I said that I wasn't going to employ excessive rhetoric, but it is worth noting a couple of statements in the Wood Report that reflect its deep hostility to derivative litigation. First, the Report uses the term "vexatious litigation ," 98 the very term, as we'll see, that is used by Rehnquist in Blue Chip (despite the fact that it appears in none of the briefs in that case). But even more, the Report examines the relationship of stockholder-plaintiff to lawyer and concludes: "This shoddy burlesque of a professional relationship to clients makes the ambulance-chaser by comparison a paragon of propriety." ${ }^{99}$

\footnotetext{
95 Donna P. Parker, Reis, Claire Raphael, The Handbook of Texas Online available at http://www.tsha.utexas.edu/handbook/online/articles/view/RR/fre51.html

${ }^{96} I d$.

${ }^{97}$ Birmingham, supra note __ at 374

${ }^{98}$ Wood, supra note _ at 48 . The term "vexatious litigation" has been in use since at least the $17^{\text {th }}$ century, according to the Oxford English Dictionary and refers to lawsuits brought without merit by "evil disposed Persons." A full etymology of the term is beyond the scope of this Article, but it is clearly meant to cast aspersions on those who are alleged to bring such suits.

${ }^{99}$ Wood, supra note _ at 47 The "ambulance chaser", by the way, was an earlier term of epithet for plaintiffs' lawyers coined by the elite WASP members of the bar. Of course they were referring largely to Jewish lawyers. Auerbach, supra note _ at 42-44.
} 
In further criticizing the lawyer-client relationship, Wood notes that " . . an inexhaustible supply of the smallest of small investors have suddenly become masters of the most intricate details of corporate finance, and the most alert of sentinels to employ attorneys and attack corporate management on the slightest suspicion of a big lawsuit." He then goes on to note the prominence of women among the plaintiffs and lists those suits which feature women plaintiffs, after which he rather sarcastically speculates as to their financial sophistication and research behavior. (Sexism, however, is not the focus of this paper.) What Wood declines to mention, but is clear to any reader, is that of the 32 listed actions, the plaintiffs in 21 of them obviously have traditional Jewish surnames, with an additional seven (for a total of 29 out of 32) having arguably Jewish surnames. It wouldn't have taken much for a reader of the time to substitute "Jews" for "women."100

More troubling, perhaps, is the disingenuous, if not downright dishonest, methodology of the Wood Report, for in detailing the alleged crisis of derivative litigation, it looks only at derivative litigation and not at all at how it fares in relation to other forms of litigation. So let's take a look at the actual numbers, starting with those set out in the Wood Report. From 1932 to 1942, Wood identified 1,400 minority stockholders' actions (1,266 after eliminating duplication), of which 693 involved close corporations (of no particular interest to us here) and 573 involved public corporations. ${ }^{101}$ Of these, thirteen cases, or $2 \%$, resulted in recovery by the corporation, 33

${ }^{100}$ Comparing Wood's text with the tables following the Wood Report, it appears that approximately $20 \%$ of plaintiffs were women, not an overwhelming proportion but, perhaps, given the time and subject matter of the suits, still an unusually large proportion. It's also interesting to note the misrepresentation of the text in light of the data presented in the tables. Given the other flaws in the Wood report, it is at least a legitimate inference that Wood chose the obviously Jewish female plaintiffs from among this $20 \%$ to present in his text.

${ }^{101}$ Wood's numbers appear in this summary discussion format at pp. 6-7. Derivative litigation against close 
(or 6\%) were settled with court approval, and 215 (or 37\%) were dismissed. Of the 342 cases not accounted for, 60 (10\%) were "settled privately" (presumably without court approval), 155 (27\%) were discontinued, 54 were still pending at the publication of the Wood Report, and there was no identifiable disposition as to the remaining 43. Wood goes on to note that in those actions that were successful (i.e., resulting in a verdict for the corporation), only about $5 \%$ of the amount claimed was recovered, and in those recoveries based upon court- approved settlements, $3 \%$ of the claimed amount was recovered. The solution to eliminating this abuse, according to Wood, is legislation in the form ultimately passed as section 61-b, which would "largely abate" "the major vices of promiscuous derivative actions. ..." 102

But how "promiscuous" were these actions and does the data support the conclusion that derivative suits presented a crisis so significant that legislation virtually eliminating them was justifiable? In order to evaluate this claim, let's look at information compiled by the State of New York as to litigation generally in the First Department. ${ }^{103}$

From 1935 through 1942, the average number of civil cases in the First Department ranged from 34,429 to 58,579 , with a mean of 51,500 cases a year in the First Department. ${ }^{104}$ The number of derivative suits (using Wood's numbers which include, without distinction, suits involving both

corporations are not of interest because they principally involve disputes among shareholders, some if not all of whom are managers, and typically involve questions of the distribution of corporate wealth among the shareholders rather than wrongdoing by officers and directors.

${ }^{102}$ Wood, supra note __ at 24

103 All of the following data is taken from the annual tables presented as this report. I have calculated the proportions. I have also left out the data from the Second Department as it is consistent with the data from the First Department and would lengthen this discussion for no appreciable gain.

${ }^{104}$ I have used the mean instead of median simply because, as the table in Appendix __ shows, they are sufficiently close that I thought the mean to be at least as representative a figure as the median. 
closely held and public corporations, and leaving aside the U.S. District Court for the Southern District of New York as to which comparable data were unavailable) ${ }^{105}$ ranged from 139 to 80 , with a mean of 109. To further put these numbers in context, during the period 1935 to 1942 , derivative suits ranged from $.41 \%$ to $.22 \%$ of all civil cases, or a mean of $.29 \%$. Put differently, out of a total of 281,423 civil cases in the First Department during this period, a grand total of 815 (or .29\%) were derivative. Since $58 \%$ of these on average involved closely held corporations, that means only 342 , or $.12 \%$, involved publicly held corporations. ${ }^{106}$

It seems fair to conclude, then, that as far as the consumption of public resources is concerned and despite the very real existence of strike suits, derivative litigation posed no significant burden. At least Wood provides no credible evidence that the negative aspects of derivative litigation (the strike suit) outweighed the positives. But there are a number of potential objections to this. First is the possibility that plaintiffs' lawyers made pre-litigation demands on boards to obtain bribes. Next is that the success rate (or even trial rate) of derivative suits was so out of proportion to that of all civil litigation that they ought to have been curbed. Third might be that derivative suits were so generally meretricious that they were disproportionately dismissed or settled. Fourth would be that the amount of recovery was so low that they were simply harassment without significant benefit to the corporation and thus had little justification.

105 The number of Second Circuit cases were a very small proportion of the total (130 out of 1,400 in all.)

106 There is no convenient way of backing out the derivative suits brought in the Second Circuit from these numbers since Wood purported to eliminate duplicative suits without indicating where they were brought. Given the relatively small number of derivative cases brought in the Second Circuit, it seems fair to conclude that they don't materially affect the results. 
As to the first objection, it may be that even if derivative litigation as litigation did not produce significant volume, plaintiffs' lawyers were using the procedures of derivative litigation to "hold up" corporations and their executives. With rare exception, a prerequisite to derivative standing is that the plaintiff has served a demand on the board to correct the action of which he complains. Perhaps plaintiffs' lawyers engaged in a practice of promiscuous demand-making, leading corporations to make payments in the nature of bribes to discourage them from filing lawsuits. If this were true, plaintiffs' lawyers could well have had a valuable business in derivative litigation that never reached general public view, and the comparative paucity of derivative suits would have no bearing on the scope of the problem which could nonetheless have been significant for corporations.

Such a story is implausible. Or rather, it is only plausible to the (implausible) extent that plaintiffs' lawyers never talked with one another and therefore the (implausible) extent to which corporations would have been able to keep such payments secret. Otherwise, as Macey and Miller note with respect to strike suits, such payments would be rare. ${ }^{107}$ The reason is that corporations that paid such bribes would rapidly become known as suckers and attractive targets for plaintiffs' lawyers, resulting in frequent and expensive demands. The only rational recourse to such demands, as it is to derivative litigation, is resistance. Thus, the "under the radar screen" argument for the significance of the strike suit problem is quite weak.

Let's take a look at the second claim, that the success rate of derivative litigation was disproportionately low compared with all civil litigation. The numbers do bear this out in

${ }^{107}$ Cf. Jonathan Macey and Geoffrey Miller, The Plaintiffs 'Attorneys'Role in Class Action and Derivative Litigation: Economic Analysis and Recommendations for Reform, 58 U. Chi. L. Rev. 1,78 (1991) ("Most observers agree that strike suit litigation is relatively uncommon.") 
percentage terms, but when one looks at the absolute numbers it appears as if litigation in general was not a terribly successful plaintiffs' endeavor (in fact it appears that litigation rarely was pursued to completion). Looking solely at jury trials, from 1934 to 1942 (the period under study), the number of cases that resulted in victory for the plaintiff after trial ranged from 458 to 609 , or from $.81 \%$ to $1.36 \%$ of all civil cases. Those that were settled or discontinued after trial ranged from 619 to 1,158 , or from $1.57 \%$ to $2.06 \%$ of all civil cases. At the same time, verdicts for defendants after trial ranged from 295 to 474 , or from $.50 \%$ to $1.00 \%$ of the total. Finally, average monetary awards to plaintiffs ranged from $\$ 5,407(\$ 59,311)$ to $\$ 7,800(\$ 101,798)$, with a mean of $\$ 6,207(\$ 79,852)$. In light of median incomes at the time, these hardly seem like exorbitant judgments. $^{108}$

There is less complete data available for bench trials that went to completion, but from 1934 to 1942 the number of completed bench trials ranged from 1,129 to 1,601 , or from 2.11 percent to 4.24 percent. Finally, the number of trials as a percentage of all cases (without regard to disposition) ranged from 1,884 to 2,216 , or from $3.51 \%$ to $6.44 \%$ of all cases on the calendar during the year.

Zlinkoff provides some interesting additional analysis. ${ }^{109}$ Noting both that the vast majority of cases never went to trial and the absence of information as to why they were discontinued (settlements, etc.), he argues that "it would seem more proper in evaluating the results of derivative suits to consider the figures for the number of suits in which issue was joined and thereafter either

${ }^{108}$ In 1944, median per capita income in the State of New York for heads of households was roughly $\$ 1,072$ $(\$ 23,276)$. This information was obtained from the staff at the United States Census Library.

${ }^{109}$ Zlinkoff, supra note __ at 362. 
the plaintiff or defendant was successful, eliminating actions that were discontinued." ${ }^{110}$ Doing so, he determines that issue was joined in 171 cases, of which 13 resulted in recoveries, and 93 in settlements, with victory for the defendant in only 65 suits. That is to say, $62 \%$ of the suits in which issue was joined resulted in stockholder victory. ${ }^{111}$ These are numbers which hardly suggest abusive litigation was prevalent.

Even more interesting are the amounts awarded either upon plaintiffs' victory or settlement, which suggest that successful derivative suits did indeed produce substantial damages. Drawing at least in part from cases in which he was involved, Zlinkoff shows us damages in seven cases from 1935 to 1944 ranging between $\$ 350,000(\$ 3,555,650$ in 2002$)$ to $\$ 4,000,000(\$ 43,877,200$ in $2002)$ with a mean of $\$ 1,665,771(\$ 20,261,105$ in 2002$)$ and a median of $\$ 1,800,000(\$ 21,893,760$ in 2002). ${ }^{112}$ While these may seem modest in light of contemporary judgments (at least in part, one suspects, because corporations were relatively smaller), ${ }^{113}$ they hardly seem out of line with the legal fees of which Wood bitterly complains. Reporting fees in twelve derivative suits (which are not, regrettably, the same cases reported by Zlinkoff but which do cover roughly the same period), we see individual defendants' legal fees ranging from $\$ 4,890$ ( $\$ 62,009$ in 2002) to $\$ 135,000$ $(\$ 1,676,241$ in 2002) with a mean of $\$ 38,178(\$ 464,627$ in 2002) and a median of $\$ 16,000$

\footnotetext{
${ }^{110}$ Id. at 362 .

111 Id. at

112 Zlinkoff, supra note _ at $362-63 .$.

${ }^{113}$ For confirmation see Shiller, IRRATIONAL EXUBERANCE; Lawrence E. Mitchell, CORPORATE IRRESPONSIBILITY: AMERICA'S NEWEST EXPORT (2001).
} 
$\left(\$ 194,611\right.$ in 2002). ${ }^{114}$ I should also point out that the $\$ 135,000$ fee was highly aberrant - the next largest fee was $\$ 71,490(\$ 869,547)$ with only two more fees over $\$ 50,000$, two in the low $\$ 30,000$ s, and the rest in the teens and below. Unfortunately Wood does not give the disposition of any of these actions. However, these fees hardly seem disproportionate to the amounts of the judgments noted by Zlinkoff and one could see them as a relatively low price to pay to enforce fiduciary obligations, especially in light of the crisis precipitated by corporate America in the 1920s. ${ }^{115}$ Thus, when more data is introduced and Wood's is carefully analyzed in context, it is hard to see derivative suits as the scourge the Wood Report makes them out to be.

Now if nothing else is clear, it should be clear that the derivative suit was relatively rarely brought and that it was very unlikely to have been used as a holdup device. When it was brought, it was hardly extraordinarily frequent compared to other terms of litigation, and in fact fares rather well against the data for all cases. And fees, while substantial, seem in line with judgments, especially when one considers that the fees are for multiple defendants. Why then, one may ask, the hysteria that led to invective and the desire to prohibit derivative suits outright?

Let's pause before going on to the last two possibilities I mentioned earlier. For you may well have detected a deficiency in my reporting. Combining the above data on the number and practice-types of Jewish lawyers in the New York bar with this report on litigation success rates, one might conclude that all types of lawsuits suffered from the same level of abuse that derivative litigation did, and wonder why the Chamber of Commerce or other groups didn't try to cut back on

\footnotetext{
${ }^{114}$ Wood, supra note __ at 8.

115 Hornstein gives the counsel fees awarded plaintiffs in 12 derivative actions between 1932 and 1939 , noting the ratios of fees to amounts awarded to the successful corporation. The median is $31 \%$, with a mean of $30 \%$. George D. Hornstein, The Counsel Fee in Stockholders 'Derivative Suits, 34 Column. L. Rev. 784, 814 (1939).
} 
the ability to bring law suits in general. After all, as I noted earlier, the elite bar had been contemptuous of Jewish lawyers and their practice generally for several decades prior to this. ${ }^{116}$ Conversely, one might wonder why I am attributing antisemitic motives to the drive to stop derivative litigation and not other forms of litigation.

The answer begins to reveal itself when one looks at the practice areas in which the Jewish bar was involved. As I reported above, the overwhelming number of Jewish lawyers represented small merchants or individual clients. Fagen reports that $42 \%$ of Jewish lawyers represented "merchants". ${ }^{117}$ The next largest proportion, $25 \%$, represented a "general" clientele, and following that, $14 \%$ reported representing corporations ${ }^{118}$ and $8.5 \%$ reported representing "wage earners and small shopkeepers." Fields of representation for Jewish lawyers fall off significantly, proportionally in the single digits, from that point. Carlin tells us that $70 \%$ of New York lawyers reported deriving at least $50 \%$ of their income from business clients, but that "most" lawyers representing corporations worked for closely held corporations. ${ }^{119}$ In addition, while large firms reported $68 \%$ of their practice as involving business, small firms and sole practitioners, where Jewish lawyers typically were found, reported $27 \%$ and $36 \%$ of their practice as involving business. Moreover, only $14 \%$ of large firms and $34 \%$ of medium firms (which we have already tables.)

${ }^{116}$ Auerbach, supra note __ at 71-2, 99-100 -101

${ }^{117}$ Fagen, supra note _ at 99. (I have extracted the proportions from the raw data provided in Fagen's

118 Recall that Jewish corporations generally were involved in the retail and wholesale trades, soft goods, entertainment and communication. It is possible that some proportion of these 419 Jewish corporate lawyers represented WASP corporations, but in light of the available evidence, hardly likely. See Baltzell, supra note Moreover, in light of Carlin's data that most Jews represented closely-held corporations, the likelihood that they would have represented major corporations seems even less.

${ }^{119}$ Carlin, supra at 13. 
seen were largely WASP) reported having a "mainly Jewish" individual clientele, whereas $46 \%$ of firms of two to four lawyers and $44 \%$ of sole practitioners reported having "mainly Jewish" individual clients. ${ }^{120}$ In light of the practice of firms (including large firms) representing the individual affairs of their business clients, and in light of the types of businesses Jews engaged in $^{121}$, one can infer, without too much difficulty, that much of the litigation that took place in New York courts took place between individuals or small businessmen, largely Jewish and represented by Jewish firms on both sides, such that WASP lawyers would be unlikely either to notice or to care.

However, it is the large WASP firm that represented large, publicly-held corporate clients, the very types of businesses that were likely to be targets of stockholder derivative suits. It is a reasonable inference, although admittedly an inference, that these firms and their clients would be far more aware of the perils of derivative litigation than of the lawsuits among the unwashed masses that took up the rest of the trial calendars. Thus it would be natural for Wood to ignore

${ }^{120}$ Carlin, supra note __ at 24.

121 Baltzell, supra note _ at 207-8, notes that "the Protestant establishment" in the 1920s and thereafter dominated "heavy manufacturing, railroad transportation and public utilities ... (along with commercial banking and insurance)" while Jews were engaged in soft goods, retail and wholesale business, and entertainment and communication business. The German Jewish aristocracy, principally involved in finance but with interests branching into railroads and mining, were exceptional. Birmingham, supra note

It is especially interesting to note WASP dominance in major industry in the 1920 s for, as I shall discuss infra, it was these industries in which the principal abuses that led to the 1929 Crash, the Pecora investigations, and passage of the securities laws of the 1930s, occurred. Thus the WASP suspicion of plaintiffs' lawyers (and the continuing contemporary suspicion of plaintiffs but not defendants) seems wholly unwarranted and, in the earlier period, can likely only be explained in terms of class which, given the structure of the bar, meant race. 
other types of litigation in his study. ${ }^{122}$ Had he not done so, his case, already weak when examined in detail, would seem to have fallen apart solely on the numbers.

In order to cross-check these inferences, I looked at every derivative suit case in the First Department of New York reported between 1920 and $1944 .{ }^{123}$ Using the admittedly unscientific (but unavoidable) technique of identifying ethnicity by surname, I found of the 64 opinions (out of 74) in which counsels' names appear, that 37 involved Jewish lawyers opposing non-Jewish lawyers, 13 involved Jewish lawyers on both sides, and 13 involved non-Jewish lawyers on both sides, with one in which there was a substantial mix of ethnicity on both sides. While hardly conclusive (and while it has never been my claim that derivative litigation was the exclusive province of Jewish lawyers), the fact that $50 \%$ of the cases involved Jews against non-Jews, and another $17 \%$ involved Jews alone, for a total of $67 \%$ of the derivative suit cases brought by Jewish lawyers, seems to provide good support for my conclusion. This of course says nothing about the ethnicity of the management of the defendant corporations, although, as we saw above, most large firms did not represent a Jewish clientele, and Jewish businesses were rather limited in type and nature. $^{124}$

${ }^{122}$ One might expect small practice Jewish lawyers to have heavily engaged in personal injury litigation, often against WASP-controlled insurance companies, and that this too would be viewed with offense by the WASP establishment. Note first that it is virtually impossible to bring a personal injury "strike suit." Typically the injury will be apparent. Moreover, a random sampling of 200 personal injury cases between 1900 and 1945 revealed obviously Jewish lawyers in fewer than $10 \%$ of cases, although Jews did appear most often for the plaintiff.

${ }^{123}$ Obviously this is a flawed enterprise in light of the relatively small number of derivative suit cases that reached trial and as to which an opinion was written, but it is the best I can do on the data available.

${ }^{124}$ In addition to the evidence already presented, see Abraham K. Korman, THE OUTSIDERS: JEWS AND CORPORATE AMERICA (1988) (evaluating the absence of Jews from the managerial ranks of most established corporations and their relatively greater presence in entrepreneurial corporations and the professions.) 
The truth of the conclusion that the push to restrict derivative litigation was motivated by antisemitism is poignantly brought home by an article published in the Michigan Law Review in 1937 by Harris Berlack, a Jewish member of the New York bar. ${ }^{125}$ The article begins by acknowledging both the paucity of studies of the methods of enforcing shareholders' rights and the general disrepute in which the derivative suit was held, despite the fact that it was the only significant process available for the enforcement of those rights. As Berlack puts it: "the stockholders' suit is universally reviled." ${ }^{126}$ Why? Not because it was easy for plaintiffs. Berlack discusses the hurdles faced by a stockholder plaintiff and his lawyer, detailing the expense, risk, and difficulty of succeeding. Having done so, he then comes to the point which, while coded, smacks undeniably of the taint of antisemitism underlying the "universal" hostility to shareholder litigation. Let me illustrate using Berlack's own words:

"In the sort of case under consideration, however, the labor involved is so great and the outcome so uncertain that the leaders of the bar are seldom inclined to take the gamble. This leaves the field to the younger and less experienced or to the less successful and sometimes less scrupulous members of the profession. Plaintiffs, as a consequence, find it difficult to obtain proper representation; and defendants must oppose tactics which are not always the most ethical, or, at the least, are subjected to an attack which is unnecessarily and unpleasantly belligerent." ${ }^{127}$

"For the abuse heaped upon the 'strikers' there may be ample justification. Unfortunately, those constantly affiliated with large corporate interests have developed the habit of placing all complaining stockholders in the same category. ${ }^{\text {"28 }}$

125 Harris Berlack, Stockholders 'Suits: A Possible Substitute, 35 Michigan L. Rev. 597 (1937). One can, as I choose to do giving Mr. Berlack the benefit of the doubt, see this piece as poignant. One can also see it, less charitably, as a classic example of Uncle-Tomism.

\footnotetext{
${ }^{126} I d$. at 599 .

${ }^{127}$ Id. at 603 (emphasis added).

${ }^{128} I d$. at 605 (emphasis added).
} 
"So intensified has become the rancor of this attitude, that the upstart who dares to question the conduct of corporate affairs is cast outside the pale of common decency." 129

"The viciousness of such attacks [of plaintiffs and their counsel] militates against their very purpose; it insures that stockholders' suits will be instituted and conducted, as a rule, only by those who are most impervious to abuse - and hence capable of the most objectionable conduct." 30

There's more. More is not needed. We already know who the "leaders of the bar" and the "less successful" lawyers were. Why should the fact that the latter were the ones willing to take on these suits lead to their revilement? "Unnecessarily and unpleasantly belligerent attacks"? An unpleasantly belligerent nature is one of the classic old antisemitic saws. "Placing all complaining stockholders in the same category"? That sounds awfully like stereotyping, and given the facts as we know them, the "category" into which all of these lawyers were put is obvious. "Upstart"? Of course these would be people who impertinently attempt to rise above their station or interfere with the activities of their betters. ${ }^{131}$ "Cast outside the pale"? The Pale of Settlement (while a borrowed term) consisted of the western areas at the edges of Russia in which Jews were permitted to live. To be outside the pale was to be completely ostracized. "Those who are most impervious to

${ }^{129} I d$. (emphasis added).

130 Id. at 606 (emphasis added).

131 Upstart indeed. John Higham illustrates this nicely: "And discrimination reflected, as it had for fifty years, a conjunction of two factors: the great but insecure inequalities of a middle class society in which men striving for distinction feared inundation; and the urgent pressure which the Jews, as an exceptionally ambitious immigrant people, put upon some of the more crowded rungs of the social ladder." John Higham,. Social Discrimination Against Jews in America, 1830-1930, in V THE JEWISH EXPERIENCE IN AMERICA (Abraham J. Karp, ed., 1969), 349, 371. And Higham goes on, describing discrimination in the period immediately before that of the Wood Report as caused by "status panic", $i d$., and sees the very success of the Jews as the cause of social antisemitism. "Whereas other European groups generally gained respect as assimilation improved their stature, the Jews reaped more and more dislike as they bettered themselves," id. at 376, and "Unfavorable stereotypes have pictured an overbearing Jewish ability to gain advantage in American life. Only one other important immigrant group - the Japanese - has normally been disliked for its strength rather than its weakness." Id. It is the temerity of Jews to challenge their betters that led to the "universal revilement" of derivative litigation. 
abuse"? Why? Because the contempt in which they are already held makes the marginal pain of further abuse insignificant, especially for the starving lawyer trying to make a living.

The coding is thin. Mr. Berlack, a Jew and New York plaintiffs' lawyer, does not want to be tarred with the same brush as his colleagues, and uses the very language of coded antisemitism to protest his own innocence. Combined with Berlack's (perhaps unintentional) self-revelation, the rhetoric of the Wood Report tells us exactly why derivative suits were considered to be such a significant problem, despite the reality of their relative innocence and the lack of serious scholarly concern with the issue. That reason is the irritation and vexation felt by WASP lawyers and their WASP clients at having to defend themselves against the annoying and decidedly low life "upstart" Jews who were demanding an equality which the WASP aristocracy was unwilling to grant them. It is counterfactual, but had the challenge of derivative litigation come from WASP - or at least Christian - lawyers, the empirical evidence suggests that there's a least a good chance that derivative litigation would not have been so "universally despised" and that any problems could have been worked out through a "gentleman's agreement."132 Recall the substantially better educational opportunities for low status Protestants and the equivalent career opportunities for law achieving Protestants compared with high achieving Jews. ${ }^{133}$ And it's not just the empirical evidence.

132 Or it could have been that poorer relation WASP lawyers would have been reluctant to take on such suits because they had a very real opportunity to rise in status within the bar, an opportunity not available to Jewish lawyers.

${ }^{133}$ See note _ and _ and accompanying text. 
I recall beginning my career at a large, "white-shoe" New York law firm in $1981 .{ }^{134}$ During my first year, I was taken under the wing of one of the senior (WASP) partners and taught to do an initial public offering. We spent a great deal of time together, both in the office and traveling back and forth to our client in Boston. As we were sitting alone in a Boston restaurant one night, well into the transaction and thus our relationship (and well into a couple of drinks) this partner paused, looked at me, and, smilingly said: “Mitchell, I like you. You can't be Jewish. You've got to be Irish." ${ }^{135}$ Irish - altbugh almost assuredly Catholic - would have been all right. Jewish simply was unacceptable.

The kind of discrimination that led to the Wood Report could well have been overt and intentional, or it could have been, and likely was, more subtle. Laura Z. Hobson's wonderful period novel, Gentleman's Agreement, ${ }^{136}$ describes antisemitism in New York among "the better sort" at the height of its American rise, the 1940s. Dramatizing the same psychological forces that Charles Lawrence describes as unconscious racism, ${ }^{137}$ Hobson shows the socially unacceptable status of even assimilated Eastern European Jews, and the psychologically subtle, subconscious defenses for discriminatory practice even among those horrified to be called antisemitic, as well as

${ }^{134}$ Not Paul Weiss which I mentioned supra at note __, and to which I later went.

135 Of course that was the day I decided to leave the firm. To be fair, this partner clearly liked me and gave me wonderful references for subsequent jobs. The simple fact (and pain) of the antidote is that he (coincidentally, a Bronxville resident) had trouble coming to grips with the fact that he so liked a Jew.

${ }^{136}$ Laura Z. Hobson, Gentleman's AgREement (1946). The novel was made into an Academy Award winning movie starring Gregory Peck, Celeste Holm, and John Garfield.

${ }^{137}$ Lawrence, supra note _.. 
the kind of pain it inflicted, the very kind of pain that could well have led to Mr. Berlack's pleas of difference. $^{138}$

A 1955 article in Look magazine, entitled The Position of the Jews in America Today, pretty much sums things up. ${ }^{139}$ The author, highly sympathetic to American Jews and critical of antisemitism, could still ask such questions, revealing ancient antisemitic allegations, as "Why are there so many Jewish organizations?" (evidently forgetting Tocqueville's description of America as a society of organizations), and "What makes Jews so clannish?" He could still make such affirmative statements as "Jews do tend to be clannish ....", "For centuries, the Jews were misfits . ..", "some Jews . . tend to be over aggressive", "a great many are hypersensitive in their relations with Gentiles" and, perhaps most astonishing of all and apparently as evidence of this last statement, "They seem to have a special exposed nerve that registers every tremor of prejudice like a seismograph: Let a Gentile use an idiomatic phrase like 'He jewed me down,' and every Jew within earshot will mark him as a bigot."

More objectively, the author could point out the continued discrimination against Jewish students in "the majority" of fraternities and sororities, quotas at medical schools and virtual exclusion from engineering schools, the substantial persistence of overt employment

${ }^{138}$ For an earlier and cruder depiction of the exclusion of even upper-class Jewry in the character of the Princeton- educated Robert Cohn, see Ernest Hemingway, THE SuN Also RISES (1926).

${ }^{139}$ Recall that this is five years before the data reported by Carlin. William Attwood, The Position of the Jews in America Today, 19 Look, No. 24, November 29, 1955.

${ }^{140}$ It is worth noting that language, even metaphorical, that describes Jews as having a "special exposed nerve" reinforces the idea of antisemitism as rooted in race or biology. 
discrimination against Jews, and the fact that, "among real estate brokers in certain areas, there is a tacit agreement not to sell to Jews."

It's hard to prove crude antisemitism as the cause of any discrimination against Jews, and Hobson illustrates this nicely in her book (although the author of the Look article unintentionally does a good job). Few people of the level of sophistication and education that characterized the eastern WASP upper classes would have been so ill-mannered as to proclaim outright their dislike of Jews and their attribution to Jews of unpleasant characteristics. (One of the ironies in Hobson's novel is that the protagonist, Phil Green, is a Stanford-educated, California-raised WASP reporter who poses as a Jew in New York society for the purpose of understanding, and writing about, antisemitism. He is tarred with precisely the same brush, and has precisely the same characteristics attributed to him, as other "Jews", simply as a result of identifying himself as Jewish.) It was the Jewishness of the plaintiff's bar that caused the derivative suit to assume crisis proportions among the WASP corporate and legal elite.

\section{Waste or Class?}

The second two reasons in defense of section 61-b, that derivative suits generally were meretricious and that recovery was so de minimus as to make them a waste of time, fall on the explanation I gave earlier. While I have not read every derivative suit opinion from this period, the data seem clear that derivative suits did not deviate terribly significantly from the norm for plaintiffs' litigation, rendering both of these explanations implausible.

There is one other possible argument that transcends antisemitism as an explanation for why derivative suits were viewed as so threatening, an argument that is highlighted by Carlin's conclusions that ethical behavior was a function of bar status. That is to suggest that the animosity 
was less driven by hatred of Jews than by class differences. But this answer is difficult, if impossible, to sustain. Were it the case that the plaintiffs' bar was made up largely of Irish and Italian lawyers, the class story might be plausible. But it wasn't. And so the argument has the initial weakness of being entirely counterfactual. Of course there was elite discrimination against these ethnic groups. But not only did it never come close to reaching the extent of antisemitism; ${ }^{141}$ they were ethnic groups that were themselves participants in the virulent antisemitism that was pervasive during the era of the Wood Report and, for the most part at that time had their own defined economic roles in the trades, the police, politics, civil service, and shopkeeping which, while somewhat humble, were never the province of the Protestant elite. ${ }^{142}$ More important, if class were the issue, then it should have been the case that lower-class Protestant lawyers were treated as poorly as Jewish lawyers, from their matriculation into college until their admission to the bar and employment in firms. But the evidence we've already examined suggests just the opposite. Lower-class Protestants, and particularly academically unsuccessful lower class Protestants, had almost the same chances to attain elite legal status as did wealthy and academically successful Jews, whereas poor and academically unsuccessful Jews had almost no chance at all. Finally, it is worth repeating that, as Baltzell sees it, the WASP elite largely defined itself in opposition to Eastern European Jewry to a far greater extent than the negligible notice taken of other ethnic minorities. The class argument falls apart on the facts. ${ }^{143}$

\footnotetext{
141 John Higham, Social Discrimination Against Jews in America, 1830-1930, in V THE JEWISH EXPERIENCE IN AMERICA (Abraham J. Karp, ed., 1969), 349, 375-6.

142 The Irish control of New York City politics through the Tammany machine, from the last quarter of the nineteenth century until the Second World War, is well known. Howe, supra note _ a 363.

${ }^{143}$ Of course it is well-known that public mistrust of lawyers in general, and especially plaintiffs' lawyers,
} 


\section{Just Who Can You Trust These Days?}

It seems obvious from the tone of the Wood Report and its conclusions that the Jewish plaintiffs' bar was completely distrusted by elite lawyers. The general environment of the New York bar, the more broadly national discussions of ethics $\operatorname{codes}^{144}$ and practices that tended to disparage and show distrust of plaintiffs' lawyers in general, and the ways in which those ethics rules did their best to limit the business of Jewish lawyers, further support this conclusion. Section 61-b was designed precisely on the basis of that mistrust. The Wood Report's implicit, and sometimes explicit, argument is that grasping and unscrupulous (Jewish) plaintiffs' lawyers were threatening the health of corporate America, a corporate America run by "the best men" society could produce. ${ }^{145}$

In light of that, it is worth asking whether the evidence supports greater trustworthiness in corporate America than in the plaintiffs' bar. Fortunately, we have both contemporaneous and then-relatively recent historical evidence to draw upon in assessing this question.

Two famous pieces of literature present themselves. The first, because roughly contemporaneous with these attitudes towards plaintiffs' lawyers and published not all that long before 61-b was enacted, is the Pecora Report which investigated the banking and securities industry abuses of the 1920s which contributed to the Crash of '29 and the Great Depression. (We

stretches far back into history and well before the history with which this article is concerned. However, the confluence of mistrust of lawyers and mistrust of Jews appears to have morphed into the antisemitic impulses of the bar. Marc Galanter points out that "A large portion of the [lawyer] jokes in the betrayal cluster are adapted from jokes that were predominantly told about Jews." Marc Galanter, The Faces of Mistrust: The Image of Lawyers In Public Opinion, Jokes, and Political Discourse, 66 U. Cin. L. Rev. 805, 827 (1998).

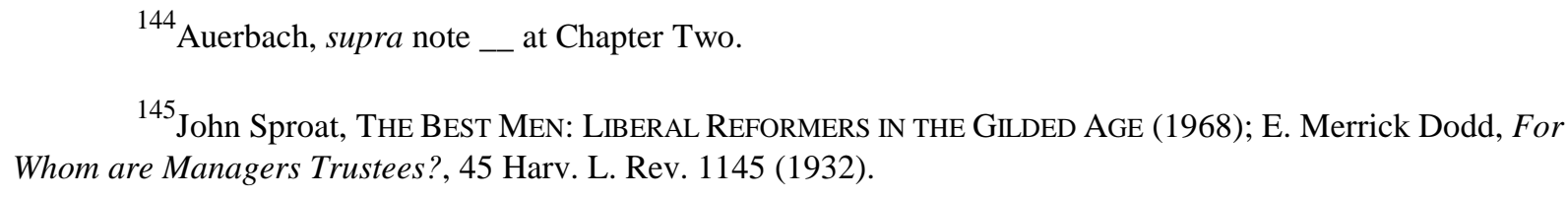


also have the benefit of a 1939 book written by Ferdinand Pecora, analyzing the extent to which corporate America had failed to reform in the wake of those hearings and the resultant enactment of the federal securities laws.) ${ }^{146}$

The second is the earlier report of the Pujo Commission ${ }^{147}$ following the Panic of 1907 which led to the passage of the Federal Reserve Act and the Clayton Act. ${ }^{148}$ The work of the Pujo Commission revealed a web of central and highly concentrated power over American industry by a small group of men, specifically in the American (WASP-dominated and WASP-represented) finance industry.

It might be worth beginning by quoting the words of Ferdinand Pecora in his 1939 assessment of the success of the securities laws in curbing corporate abuses:

Under the surface of the governmental regulation of the securities market, the same forces that produced the riotous speculative excesses of the "wild bull market" of 1929 still give evidences of their existence and influence. Though repressed for the present, it cannot be doubted that, given a suitable opportunity, they would spring back into pernicious activity.

Frequently we are told that this regulation has been throttling the country's prosperity. Bitterly hostile was Wall Street to the enactment of the regulatory legislation. It now looks forward to the day when it shall, as it hopes, reassume the reins of its former power.

That its leaders are eminently fitted to guide our nation, and that they would make a much better job of it than any other body of men, Wall Street does not for a moment doubt. Indeed, if you now hearken to the oracles of The Street, you will hear now and then that the money-changers

${ }^{146}$ Pecora Report; Ferdinand Pecora, Wall Street Under OAth: The Story OF OUR Modern Money Changers (1939). From January, 1933 to July, 1934, Pecora was counsel to the United States Senate Committee on Banking and Currency which conducted the investigation.

${ }^{147}$ Money Trust Investigation: Investigation of Financial and Monetary Conditions in the United States under House Resolutions Nos. 429 and 504 before a Subcommittee of the Committee on Banking and Currency: Interlocking Directorates (1913). The Pujo Commission is named after Louisiana congressman Arsene Pujo who was chair of the subcommittee.

14812 USCS § $226(2002)$

15 USCS $\S 12$ (2002) 
have been much maligned. You will be told that a whole group of high-minded men, innocent of social or economic wrongdoing, were expelled from the temple because of the excesses of a few. .

These disingenuous protestations are, in the crisp legal phrase, without merit. The case against the money- changers does not rest upon hearsay or surmise. It is based upon a mass of evidence, given publicly and under oath before the Banking and Currency Committee of the United States Senate in 1933-1934, by The Street's mightiest and best-informed men. Their testimony is recorded in twelve thousand printed pages ....

The public, however, is sometimes forgetful. ${ }^{149}$

Granted that Pecora had a legacy to protect, the evidence assembled by the Commission was overwhelming. Wall Street simply was not to be trusted. And Wall Street controlled corporate America.

The same conclusions are even clearer in the Pujo Commission report, which includes elaborate tables detailing the extent to which major financial institutions had interlocking directorates across the scope of corporate America. To quote a summary of the report's findings:

The firm members and directors whose affiliations are thus shown number 180 . In the aggregate they hold 385 directorships in 41 banks and trust companies . . .50 directorships in 11 insurance companies . . .155 directorships in 31 railroad systems . . 6 directorships in 2 express companies and 4 directorships in 1 steamship company . . .98 directorships in 28 producing and trading corporations . . . and 48 directorships in 19 public utility corporations . . . in all, 746 directorships in 134 corporations having total resources or capitalization of $\$ 25,325,000,000 .{ }^{150}$

By itself, the fact that a small group of men in the American financial industry controlled all other major industries doesn't mean they were untrustworthy. It does suggest, however, that nobody was watching them but themselves. If nothing else, this should underscore the need for some kind of watchdog, and the only available one at the time was the plaintiffs' lawyer acting as private attorney general. Even after the passage of the Federal Reserve Act, the Clayton Act, the

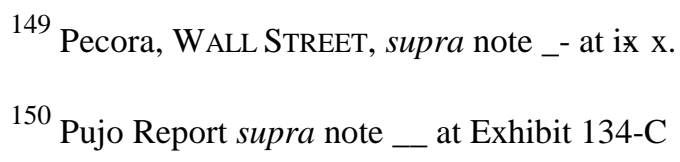


Glass-Steagall Act, and the securities laws, significant corporate abuses continued as Pecora reports. $^{151}$

So why trust corporate managers? They'd already let America down in very significant ways - twice in twenty years. ${ }^{152}$ And, as I noted above, derivative litigation was a very small part of judicial business and the securities class action hadn't even been invented yet. What reason did the New York elite bar, Chamber of Commerce, and legislature have to assume that plaintiffs' lawyers were generally less trustworthy than corporate managers? It would appear that they had none, except the deep mistrust of the mostly Jewish plaintiffs' bar which went with American antisemitism in general.

It isn't quite so easy just to leave things at this point though. As I noted earlier, the purpose of the Carlin report was to examine the ethical behavior of New York lawyers. We've already seen the stratification of the bar which remained consistent between 1939 and Carlin's work. Carlin concludes in his study that understanding the stratification of the bar is "essential" to understanding the forces that determine lawyers' ethical behavior. ${ }^{153}$

Here Jewish lawyers fared less well. Carlin concludes that in general large firm lawyers whom, as we have seen, were mostly WASP, were more likely to conform to explicit ethical norms than smaller firm lawyers whom we have seen were more likely to be Jewish. From this one might

${ }^{151}$ Pecora, supra note _..

152 Actually financial panics were far more frequent in the nineteenth and early twentieth centuries, occurring at least in 1837, 1857, 1873, 1903, and 1907.

${ }^{153}$ Carlin, supra note __ at 23. 
conclude that it was indeed rational to distrust the plaintiffs' bar. But not so fast. For Carlin concludes:

Viewed alone, ... [ [the data] suggests a direct connection between cultural or religious characteristics and conformity with ethical norms. However, further analysis of the data indicates that the significance of ethnicity is largely confined to the role it plays in allocating lawyers to different status positions in the bar and in exposing them to different pressures. ${ }^{154}$

In other words, Carlin found that when lawyers of different ethnicity were of equal status in the bar, ethnicity was "virtually eliminated" as a factor in ethical compliance. ${ }^{155}$ The extent that Jewish lawyers were more likely to violate explicit ethical norms than Protestant lawyers is a clear function of the stratification of the bar based on antisemitism.

Even if Jews were more likely to violate explicit ethical norms, can we conclude that they were intrinsically less trustworthy? Two other aspects of the ethical dimension suggest not, and further suggest that their ethical violations were for the most part far more innocuous than the social and economic damage wrought by corporate managers and their counsel. The first aspect is the type of ethical rules that lower-status lawyers tended to violate, none of which go the issues raised in the Wood Report nor are likely to be relevant in a sophisticated, large firm corporate practice. The second is the fact that the ethics rules themselves were drafted on a rather explicit background of antisemitism, and that many of the rules (such as the prohibition on advertising) were explicitly designed to damage the prospects of Jewish lawyers and thereby discourage them from becoming members of the bar in the first place.

\footnotetext{
${ }^{154}$ Carlin, supra note __ at 126.

${ }^{155}$ Carlin, supra note __ at 126.
} 
First let's look at the types of ethical violations used in the study. Before doing so, it is worth remembering that the ethics rules we are dealing with are not rules of morality, but are instead positive rules that were constructed and adopted by the bar. As every law student comes to understand, the ethics rules are even sometimes counterintuitive, and are designed to permit consistent self-regulation of the bar. As I'll shortly describe, some of the ethical violations Carlin uses are clearly wrong and indefensible under any system of ethics. Others are more ambiguous, obviously arising from the need to make a living under the circumstances I earlier described. Still others have little if any moral content (like the prohibition on advertising) and may themselves derive from wrongful policies, like creating barriers to entry to prevent excessive competition.

I lack the space to explain in detail all of Carlin's categories, ${ }^{156}$ but a brief listing of them should at least indicate the nature of the violations. Recited like the ten plagues visited upon Egypt at the Passover Seder, they are: kickbacks to clients for referral of other clients, conflicts of interest, purchasing stock in a corporation to which the assets of a bankrupt client corporation are to be transferred, sending Christmas cards to all clients, overlooking a client's bribe of a tax or other governmental official, accepting ordinary commissions from title insurance companies without informing the client, recommending an "almost fair" settlement offer to client in exchange for future concessions from the insurance adjuster, accepting a referral fee from another lawyer, misinforming client as to the weakness of the state's case against him to ensure continued installments on fees, agreeing to take divorce case where parties agree to consent decree on the basis of adultery although no adultery was committed (adultery being the only ground for divorce in New York), following client's instructions to disregard oral agreement with other lawyer in 
order to take a better deal, bribing police to get charge of homosexuality against "promising youth" removed from records, and insider trading. ${ }^{157}$

As one can readily see, some of the actions that are considered violations (having the records purged of charges of a dubious crime for a "promising youth", referral fees, the divorce consent decree, and sending Christmas cards to clients) are at least morally defensible. Some of these are also based on ethical restrictions that are downright anticompetitive (referral fees, Christmas cards). Others, while violations of a client's trust, are not seriously wrongful (accepting a normal title insurance commission without disclosure). Most of the others are unambiguously wrong, but one can see their clear relationship to a lawyers' ability to survive. One can also see that the situations in which most of these violations occur wouldn't even come up in the large firm corporate context. And it should be quite clear that none of these violations relate to the kinds of issues that come up in derivative litigation. Thus the implication that corporate managers are somehow more trustworthy than plaintiffs' lawyers seems to fail, especially when the serious national economic damage those corporate managers caused during the first thirty years of the previous century and the beginning of this one is compared with the relatively petty nature of most of the ethical offenses identified above.

\section{Class Actions}

The second type of stockholder litigation which has been subjected to significant restrictions is that under the federal securities laws and, most importantly, section 10(b) and rule 10b-5 of the Securities Exchange Act of 1934. The reason for discussing class actions, despite the

${ }^{156}$ Carlin, supra note __ at 44-5 explains them in detail.

${ }^{157}$ Carlin at $44-5$. 
fact that all of the hard evidence relates to derivative suits, is because class actions effectively supplanted derivative suits as the principle means by which stockholders seek redress. As such, they have been subject to the same opprobrium as derivative suits, and indeed it is class action suits which were the target of the 1995 Act.

As with derivative litigation, the issue on which I'd like to focus is standing to sue (the securities for expense statute can be seen as a standing matter since a plaintiff who fails to comply loses his standing to sue.) Under section 10(b) and rule 10b-5, it is unlawful for any person "to use or employ, in connection with the purchase or sale of any security ... any manipulative or deceptive device or contrivance" that contravenes SEC rules (rule 10b-5 being the operational rule). Prior to 1975 , the federal courts, principally the Second Circuit where most securities litigation took place, and the Supreme Court, had been struggling to flesh out the meaning of this rather cryptic enabling statute (and the equally cryptic rule.) Both courts, however, were guided by the general policy that since the securities acts were remedial in nature, they were to be liberally interpreted. In general, although the courts did impose reasonable restrictions, it's fair to say that they were in fact liberally interpreted.

From 1975 on, it's equally fair to say that the Supreme Courts' securities jurisprudence has been an aggressive and unprincipled cutting back on plaintiffs' rights under the securities laws. The landmark case (symbolizing the real start of the cutback) was Blue Chip Stamps v. Manor Drug Stores $^{158}$ in which then-Justice Rehnquist, in his only securities law opinion, wrote an incoherent opinion (based on none of the briefs in the case) largely turning on the fear of

158421 U.S. 723 (1975). 
"vexatious litigation", a phrase that rings with the tones of distrust we've been following through the second part of the twentieth century. ${ }^{159}$

Following Blue Chip were cases in which the Court limited defendants' liability under the '33 Act by, among other things, defining a "prospectus" (as to which legal action could be taken) as not a prospectus, limiting the statute of limitations under the antifraud rules of the ' 34 Act to a total of three years from the fraud (regardless of the fact that the essence of fraud is concealment and it is more than possible to take longer than three years to uncover a business fraud), eliminating liability for misleading proxy statements if the proxy statement was sent voluntarily by the company rather than legally mandated, and eliminating aiding and abetting liability under the ' 34 Act antifraud provisions (which was the principal way plaintiffs were able to hold lawyers and accountants liable for fraud under the Act, a questionable move at the time and one made even more so by the Enron debacle). ${ }^{160}$

The low point of the cutback was, however, brought to us by Congress, in its passage of The Private Securities Litigation Reform Act of 1995. While there are many aspects of that statute to criticize, including procedural devices to restrict the number of plaintiffs' firms that can bring suit, the most troubling aspects of the statute are a heightened state of mind requirement (plaintiff must prove that defendant knew of the fraud instead of the earlier mere recklessness, surely a very difficult task in most cases), the elimination of joint and several liability by the apportionment of

${ }^{159}$ It is worth recalling that one issue that arose during Rehnquists' confirmation hearing was his ownership of property, the deed of which contained a restrictive covenant against sales to Jews. At the very least this suggests gross insensitivity.

160 See Lawrence E. Mitchell, No Business Like No Business, in THE REHNQUIST COURT, (Herman Schwartz, ed. forthcoming 2002) for a discussion of these cases. 
fault with a corresponding limitation on damages (thus further creating financial disincentives for plaintiffs to sue), unusually burdensome pleading requirements (almost impossible to meet before discovery), and protection from the antifraud rules for forward - looking statements by a corporation as long as the statement is qualified by a phrase suggesting that it be taken with a grain of salt (hardly a difficult task for corporations to meet and protecting misleading statements completely. $)^{161}$

I'm not going to claim that this Act, like the New York statute, was proximately caused by antisemitism. Both the demographics of the bar and our social norms have changed far too dramatically to make that assertion sustainable. But there are some interesting aspects of the Act and its passage which suggest that the attitudes which prompted it are not far removed from the antisemitism that led to section 61-b.

The 1995 Act was a legacy of the Contract with America, the brainchild of Newt Gingrich in his attempt to take over the House of Representatives during the 1994 mid-term elections. Among the actions under the Contract promised by its signatories within the first 100 days of the $104^{\text {th }}$ Congress was the so-called "Common Sense Legal Reform Act", which included both reform of products liability litigation and the 1995 Act. Products liability litigation reform, while it initially passed, could not override the President's veto. The 1995 Act passed, overriding President Clinton's veto, on a vote of 68-30 in the Senate (with 20 Democrats voting in favor) and 319-100-1 in the House (with 89 Democrats voting in favor). Particularly unusual, as I earlier mentioned, is that a review of the legislative history of the 1995 Act reveals virtually no empirical evidence as to the losses (including virtually no evidence of the loss to corporate productivity), if any, caused by

${ }^{161}$ P.L. 104-67 (1995). 
stockholder litigation, and absolutely no empirical evidence as to the benefits. ${ }^{162}$ Of course there are strike suits, and limitations on them are important. But there is no hard evidence that the limitations in this act were anything but overkill. Why did such a poorly conceived bill pass, and why this and not products liability legislation as well? ${ }^{163}$

For one thing, the 1995 Act was at least in large part passed because of the enormous lobbying pressure brought to bear on Congress by Silicon Valley corporations, corporations the stock volatility and failure rate of which was much higher than the norm and the executives of which wanted protection from lawsuits filed every time their stock price dropped ten percent. But this can't be the entire explanation, for high tech corporations are geographically concentrated and corporations subject to products liability suits are located throughout the country. It should have been the case, then, that Congress was subject to at least as much pressure (or at least pressure more broadly felt) in the products liability area than in the securities area. ${ }^{164}$

Another possibility is that personal injury plaintiffs' lawyers also are located throughout the United States, whereas stockholders' plaintiffs' lawyers are concentrated in a very few cities, especially in the northeast and most particularly in New York where the acknowledged principal target of the legislation, the largely Jewish Milberg, Weiss, has its main office. Most

${ }^{162}$ Hillary A. Sale, Judging Heuristics, 35 U.C. Dav. L. Rev. 903 at n. 57.

163 It is important to remember that both pieces of legislation were part of the Republican Contract with America, a House-generated document, and to note that not a single House Republican voted against the override of the President's veto of the 1995 Act. (A very few Senate Republicans voted against the override.)

Also note that while the House mustered 319 votes to override the President's veto of the 1995 Act, only 258 votes were cast in the House to override the veto of the products liability reform act. This removed almost all Democrats from the override, leaving it to the House Republicans whose public commitment it was to pass that act.

164 Of course it's possible the high tech industry was better organized, and that it also spread its campaign largess over a far broader sweep than Northern California. 
congresspeople would have very little concern with such a localized interest group, where they would be much more concerned with the kinds of lawyers that practiced in their own districts. So simple public choice explanations could suffice.

But the rush to legislate on this subject, and the contempt for plaintiffs' lawyers obvious in the hearings records, suggests another possibility. Not explicit antisemitism. But perhaps an attitude, the origins of which would not likely have been visible to Congress, an attitude arising in the very antisemitism that led to section $61-b .^{165}$

Racism? Not necessarily. Jody Armour has made the interesting argument that stereotypes persist even in the minds of low - prejudiced people long after prejudice itself is gone. ${ }^{166}$ And to read the record of the hearings is to see the repeated stereotype of the grasping, unscrupulous plaintiffs' lawyer. If this is the case, at least with respect to most of those who voted in favor of the bill (for, as I noted, they had almost no hard information on which to vote), it is less troubling than is the passage of Section 61-b, but does call for a conscious examination of the origins of these stereotypes and, as we can see with respect to the 1995 Act, it leads us to reactive rather than considered public policy. So stereotypes, even deracinated ones, are harmful enough.

But was there no antisemitism? The repeated litany of the Jewish names of the members of the plaintiffs' securities bar at least raises a question, at least with respect to some congresspeople (I have nobody particular in mind.) Racism can be unconscious. It can be conscious. But conscious or unconscious, it is beyond dispute that the burden of the 1995 Act fell quite

165 It is interesting to note that Senator Boxer, a Jew from Northern California where Silicon Valley is located, voted neither for the original bill nor the override, presumably at some political peril from her wealthy constituents who were lobbying so vociferously for its passage.

166 Armour, supra note _.. 
disproportionately upon urban, and especially New York, Jewish lawyers. The echoes of 1944

should at least make us stop and think.

\section{Appendix A}

Jewish Census Information

Demographics in $1937^{1}$

\begin{tabular}{|l|r|r|r|}
\hline & $\begin{array}{l}\text { Jewish Population } \\
\text { Estimate (American } \\
\text { Jewish Yearbook } \\
1937)^{2}\end{array}$ & $\begin{array}{l}\text { General Population } \\
\text { (American Jewish } \\
\text { Yearbook 1937) }\end{array}$ & Percent Jewish \\
\hline Manhattan & 351,037 & $1,870,225$ & $18.77 \%$ \\
\hline Brooklyn & 974,765 & $2,630,456$ & $37.06 \%$ \\
\hline Bronx & 592,185 & $1,349,621$ & $43.88 \%$ \\
\hline Queens & 107,855 & $1,227,659$ & $8.79 \%$ \\
\hline $\begin{array}{l}\text { Richmond (Later } \\
\text { Staten Island) }\end{array}$ & 9,158 & 167,354 & $5.47 \%$ \\
\hline Total New York City & $2,035,000$ & $7,245,315$ & $28.09 \%$ \\
\hline
\end{tabular}

${ }^{1}$ Jacob Rader Marcus has done extensive research on the Jewish people in America. Among his research data, he has found data on populations of Jews in various cities in the United States. See Marcus, Jacob Rader: To COUnT A PEOPle: AmERICAN JeWISH Population Data, 1585-1984 (University Press of America Boston 1990), Page 139 for NY State.

Marcus cites Universal Jewish Encyclopedia in an estimate that 2,100,000 Jews lived in New York City in 1939. No numbers or estimates were available for each of the boroughs for 1939. However, Marcus cites American Jewish Yearbook for 1937 numbers broken down by borough. For 1940, Marcus cites Horowitz and Kaplan for a borough breakdown. For the number of Jews, the 1940 numbers only add up to 1,784,000 (Marcus citing Horowitz and Kaplan). Note that Horowitz and Kaplan were far more conservative on the number of Jews in NYC than AJYB. However, both primary sources (AJYB and Horowitz/Kaplan) seem to be experts on Jewish populations in the United States, so it is unclear whose numbers would be most accurate.

${ }^{2}$ By backtracking the American Jewish Yearbook's numbers, it seems that AJYB created its estimates of the Jewish population using a top down method. Taking arbitrarily chosen percentages times the total estimated number of Jews in New York City $(2,035,000)$, the authors simply allocated the Jews among the five boroughs. The percentages used are as follows: Manhattan 17.25\%, Brooklyn 47.90\%, Bronx 29.10\%, Queens 5.30\%, and Richmond (Staten Island) $0.45 \%$.

\footnotetext{
3 "General Population", as used in these tables, refers to the population of New York.
} 
1940 Demographics

\begin{tabular}{|l|r|r|r|}
\hline & $\begin{array}{l}\text { Jewish Population } \\
\text { Estimate } \\
\text { (Horowitz/Kaplan) }\end{array}$ & $\begin{array}{l}\text { General Population } \\
\text { (1940 U.S. Census) }\end{array}$ & Percent Jewish \\
\hline Manhattan & 270,000 & $1,889,924$ & $14.29 \%$ \\
\hline Brooklyn & 857,000 & $2,698,285$ & $31.76 \%$ \\
\hline Bronx & 538,000 & $1,394,711$ & $38.57 \%$ \\
\hline Queens & 115,000 & $1,297,634$ & $2.29 \%$ \\
\hline $\begin{array}{l}\text { Richmond (Later } \\
\text { Staten Island) }\end{array}$ & 4,000 & 174,441 & $23.93 \%$ \\
\hline Total New York City & $1,784,000$ & $7,454,995$ & \\
\hline
\end{tabular}


1960 Demographics ${ }^{1}$

\begin{tabular}{|l|r|r|r|}
\hline & $\begin{array}{l}\text { Population Estimate } \\
\text { of Jewish People } \\
\text { (American Jewish } \\
\text { Yearbook 1960) }\end{array}$ & $\begin{array}{l}\text { General Population } \\
\text { (1960 U.S. Census) }\end{array}$ & Percent Jewish \\
\hline Manhattan & 293,000 & $1,698,281$ & $17.25 \%$ \\
\hline Brooklyn & 794,000 & $2,627,319$ & $30.22 \%$ \\
\hline Bronx & 432,000 & $1,424,815$ & $30.32 \%$ \\
\hline Queens & 408,000 & $1,809,578$ & $22.55 \%$ \\
\hline $\begin{array}{l}\text { Richmond (Later } \\
\text { Staten Island) }\end{array}$ & 10,000 & 221,991 & $4.50 \%$ \\
\hline Total New York City & $1,937,000$ & & $24.89 \%$ \\
\hline
\end{tabular}

${ }^{1}$ For Carlin's year (1960), much more information was found. The Marcus data for 1960 cites AJYB, and the total population data comes from the U.S. Census taken in 1960. 


\section{Appendix B}

Law Schools Attended by Jewish Lawyers ${ }^{1}, 1939$

\begin{tabular}{|l|l|l|}
\hline Law School & Number & Percentage \\
\hline Brooklyn Law School & 773 & 25.8 \\
\hline New York University & 679 & 22.7 \\
\hline New York Law School & 364 & 12.1 \\
\hline Columbia & 329 & 11.0 \\
\hline St. John's & 322 & 10.7 \\
\hline Fordham & 188 & 6.2 \\
\hline Harvard & 122 & 4.0 \\
\hline Yale & 27 & 0.9 \\
\hline Cornell & 23 & 0.7 \\
\hline Others & 48 & 1.6 \\
\hline Not Indicated & 112 & 3.7 \\
\hline
\end{tabular}

${ }^{1}$ Fagen at 97. 


\section{Appendix C}

Types of Principal Clients and Median 1939 Incomes of Jewish Lawyers ${ }^{1}$

\begin{tabular}{|l|l|l|l|l|}
\hline $\begin{array}{l}\text { Type of Principal } \\
\text { Clients }\end{array}$ & $\begin{array}{l}\text { Number of } \\
\text { Lawyers } \\
\text { Reporting }\end{array}$ & $\begin{array}{l}\text { Percentage of } \\
\text { Lawyers } \\
\text { Reporting }\end{array}$ & $\begin{array}{l}\text { Median Income } \\
\text { (1937 Dollars) }\end{array}$ & $\begin{array}{l}\text { Median } \\
\text { Income (2002 } \\
\text { Dollars) }\end{array}$ \\
\hline Banks & 51 & $1.72 \%$ & 7,604 & $97,812.32$ \\
\hline Stock Brokers & 15 & $0.51 \%$ & 5,938 & $76,382.11$ \\
\hline Corporations & 419 & $14.12 \%$ & 4,968 & $63,904.74$ \\
\hline Theatrical, Radio & 16 & $0.54 \%$ & 4,333 & $55,736.56$ \\
\hline Trade Associations & 13 & $0.44 \%$ & 4,250 & $54,668.91$ \\
\hline Trade Unions & 23 & $0.77 \%$ & 4,000 & $51,453.09$ \\
\hline $\begin{array}{l}\text { Insurance } \\
\text { Companies and } \\
\text { Brokers }\end{array}$ & 26 & $0.88 \%$ & 3,800 & $48,880.43$ \\
\hline Garment Industry & 103 & & & $37,388.29$ \\
\hline General & 783 & $3.47 \%$ & 3,684 & $37,432.12$ \\
\hline Manufacturers & 42 & $26.38 \%$ & 2,910 & $36,017.16$ \\
\hline Real Estate & 192 & $1.42 \%$ & 2,800 & $35,052.42$ \\
\hline Building Trades & 20 & $6.47 \%$ & 2,725 & $30,871.85$ \\
\hline Merchants & 1252 & $0.67 \%$ & 2,400 & $30,254.42$ \\
\hline $\begin{array}{l}\text { Wage Earners and } \\
\text { Small Shopkeepers }\end{array}$ & 251 & $42.18 \%$ & 2,352 & $18,188.67$ \\
\hline $\begin{array}{l}\text { Person Charged } \\
\text { with Crimes }\end{array}$ & 31 & $8.46 \%$ & 1,414 & $16,477.85$ \\
\hline Others & 184 & $1.04 \%$ & 1,281 & $34,808.01$ \\
\hline
\end{tabular}

\footnotetext{
${ }^{1}$ Fagen at 99.
} 


\section{Appendix D}

Median 1939 Income of Jewish Lawyers Classified by Organization of Law Practice ${ }^{1}$

\begin{tabular}{|l|l|l|l|l|}
\hline $\begin{array}{l}\text { Organization of } \\
\text { Practice }\end{array}$ & $\begin{array}{l}\text { Number } \\
\text { Reporting }\end{array}$ & Percentage & $\begin{array}{l}\text { Median Income } \\
(1937 \text { Dollars })\end{array}$ & $\begin{array}{l}\text { Median } \\
\text { Income } \\
\text { (2002 Dollars })\end{array}$ \\
\hline Solo Practitioner & 1,752 & $61.00 \%$ & 1,874 & 24,105 \\
\hline Head of Office & 192 & $6.69 \%$ & 8,879 & 114,213 \\
\hline Member of Firm & 429 & $14.94 \%$ & 4,137 & 53,215 \\
\hline Employee of Firm & 411 & $14.31 \%$ & 2,157 & 27,745 \\
\hline $\begin{array}{l}\text { Employed on } \\
\text { Legal Staff of } \\
\text { Business }\end{array}$ & 88 & $3.06 \%$ & 3,960 & 50,939 \\
\hline $\begin{array}{l}\text { Total for Jewish } \\
\text { Lawyers }\end{array}$ & 2,872 & $100.00 \%$ & 2,426 & 31,206 \\
\hline
\end{tabular}

\footnotetext{
${ }^{1}$ Fagen at 96.
} 


\section{Appendix E}

Organization of Legal Practice by Years of Practice for Jewish Lawyers and General New York City Bar $^{1}, 1939$

\begin{tabular}{|l|l|l|l|l|l|l|l|l|}
\hline $\begin{array}{l}\text { Years of } \\
\text { Practice }\end{array}$ & \multicolumn{2}{l|l}{$\begin{array}{l}\text { Single } \\
\text { Practitioners }\end{array}$} & \multicolumn{2}{l|}{$\begin{array}{l}\text { Heads of } \\
\text { Offices }\end{array}$} & \multicolumn{2}{l|}{ Firm Members } & \multicolumn{2}{l|}{ Employees } \\
\hline & J & G & J & G & J & G & J & G \\
\hline $0-4$ & 54.35 & 40.59 & 1.04 & 7.91 & 34.85 & 12.23 & 9.74 & 39.27 \\
\hline $5-10$ & 69.29 & 42.46 & 2.46 & 14.38 & 18.06 & 21.00 & 11.82 & 22.16 \\
\hline $11-16$ & 64.65 & 35.45 & 7.40 & 20.90 & 8.00 & 32.38 & 19.93 & 11.27 \\
\hline $17-23$ & 57.93 & 36.53 & 15.45 & 18.75 & 4.29 & 35.34 & 22.31 & 9.38 \\
\hline $24-34$ & 58.81 & 29.85 & 21.26 & 33.38 & 2.71 & 31.53 & 17.19 & 5.24 \\
\hline $35+$ & 41.66 & 29.43 & 28.12 & 27.93 & 1.04 & 39.62 & 29.16 & 3.02 \\
\hline
\end{tabular}

"J" stands for Jewish lawyers, and "G" stands for general membership of the Bar.

\footnotetext{
${ }^{1}$ Fagen at 101.
} 


\section{Appendix F}

Median Net Incomes for Jewish Lawyers (1937) and General Bar Membership (1933) According to Experience $^{1}$

\begin{tabular}{|l|l|l|l|l|}
\hline Years of Practice & $\begin{array}{l}\text { Jewish Lawyers } \\
\text { (1937 Dollars) }\end{array}$ & $\begin{array}{l}\text { Jewish Lawyers } \\
\text { (2002 Dollars) }\end{array}$ & $\begin{array}{l}\text { General Lawyers } \\
\text { (1933 Dollars) }\end{array}$ & $\begin{array}{l}\text { General Lawyers } \\
\text { (2002 Dollars) }\end{array}$ \\
\hline $0-4$ & 1,031 & $13,262.03$ & 1,794 & $24,812.40$ \\
\hline $5-10$ & 2,070 & $26,626.97$ & 3,164 & $43,760.56$ \\
\hline $11-16$ & 3,408 & $43,838.03$ & 5,547 & $76,719.28$ \\
\hline $17-23$ & 5,378 & $69,178.68$ & 6,647 & $91,933.13$ \\
\hline $24-34$ & 4,907 & $63,120.08$ & 6,572 & $90,895.82$ \\
\hline $34+$ & 5,000 & $64,316.36$ & 8,068 & $111,586.70$ \\
\hline
\end{tabular}

\footnotetext{
${ }^{1}$ Fagen at 92.
} 


\section{Appendix G}

Nativity of Jewish Lawyers and of General New York City Bar Membership, $1939^{1}$

\begin{tabular}{|l|l|l|}
\hline Nativity & Jewish (\%) & General (\%) \\
\hline Native-Born & $68.6 \%$ & $80.8 \%$ \\
\hline Foreign-Born & $17.8 \%$ & $18.6 \%$ \\
\hline Not Specified & $13.5 \%$ & $0.6 \%$ \\
\hline
\end{tabular}

\footnotetext{
${ }^{1}$ Fagen at 79.
} 


\section{Appendix $\mathrm{H}$}

Type of College Attended by Religion and Social Class Background, 1960 ${ }^{1}$

\begin{tabular}{|l|l|l|l|l|l|l|}
\hline & \multicolumn{6}{l|}{$\begin{array}{l}\text { Percent of lawyers who attended an Ivy League or top-quality } \\
\text { college outside New York City }\end{array}$} \\
\hline Religion & \multicolumn{2}{l|}{ High Parental SES } & \multicolumn{2}{l|}{$\begin{array}{l}\text { Middle Parental } \\
\text { SES }\end{array}$} & \multicolumn{2}{l|}{ Low Parental SES } \\
& Percent & Number & Percent & Number & Percent & Number \\
\hline & 70 & 64 & 42 & 12 & 28 & 18 \\
\hline Protestant & 34 & 169 & 17 & 133 & 9 & 211 \\
\hline Jewish & 19 & 47 & 10 & 21 & 10 & 52 \\
\hline
\end{tabular}

\footnotetext{
${ }^{1}$ Carlin at 29.
} 


\section{Appendix I}

Membership in Large Firms by Type of Law School, Law School Standing, and Religion¹, 1960

\begin{tabular}{|l|l|l|l|l|l|l|l|}
\hline \multicolumn{2}{|l|}{ Type of Law School } & \multicolumn{2}{l|}{ Protestant } & \multicolumn{2}{l|}{ Catholic } & \multicolumn{2}{l|}{ Jewish } \\
\hline \multicolumn{2}{|l|}{} & $\%$ & $\#$ & $\%$ & $\#$ & Percent & Number \\
\hline $\begin{array}{l}\text { Full-Time } \\
\text { University }\end{array}$ & $\begin{array}{l}\text { Law } \\
\text { Review }\end{array}$ & 69 & 13 & 0 & 5 & 11 & 27 \\
\hline & $\begin{array}{l}\text { All } \\
\text { Others }\end{array}$ & 26 & 54 & 40 & 20 & 8 & 116 \\
\hline $\begin{array}{l}\text { Mixed Law } \\
\text { School }\end{array}$ & $\begin{array}{l}\text { Law } \\
\text { Review }\end{array}$ & 0 & 2 & 24 & 17 & 3 & 59 \\
\hline & $\begin{array}{l}\text { All } \\
\text { Others }\end{array}$ & 10 & 30 & 5 & 82 & 0 & 343 \\
\hline
\end{tabular}

\footnotetext{
${ }^{1}$ Carlin at 31.
} 


\section{Appendix $\mathbf{J}$}

Membership in the Two Main City Bar Associations by Size of Firm ${ }^{1}, 1960$

\begin{tabular}{|l|l|l|l|l|}
\hline $\begin{array}{l}\text { Bar } \\
\text { Association }\end{array}$ & Large Firm & Medium & Small & $\begin{array}{l}\text { Solo } \\
\text { Practitioner }\end{array}$ \\
\hline $\begin{array}{l}\text { Association of } \\
\text { the Bar of the } \\
\text { City of New } \\
\text { York }\end{array}$ & 61 & 36 & 13 & 10 \\
\hline $\begin{array}{l}\text { New York } \\
\text { County } \\
\text { Lawyers? } \\
\text { Association }\end{array}$ & 27 & 41 & 50 & 47 \\
\hline
\end{tabular}

\footnotetext{
${ }^{1}$ Carlin at 36.
} 


\section{Appendix K}

Disposition of Derivative Shareholder Suits by Year 1930-1942

\begin{tabular}{|c|c|c|c|c|c|c|c|c|}
\hline Year & $\begin{array}{l}\text { Jurisdi } \\
\text { ction }\end{array}$ & $\begin{array}{l}\text { Number } \\
\text { of Suits } \\
\text { (Not } \\
\text { Including } \\
\text { Consolida } \\
\text { ted Suits) }\end{array}$ & $\begin{array}{l}\text { Percenta } \\
\text { ge of } \\
\text { Successf } \\
\text { ul Suits }\end{array}$ & $\begin{array}{l}\text { Percentage } \\
\text { of "Strike } \\
\text { Suits"3 }\end{array}$ & $\begin{array}{l}\text { Percentage } \\
\text { Plaintiff's } \\
\text { Losses } \\
\text { based on } \\
\text { Judgments } \\
\text { on the } \\
\text { Merits }\end{array}$ & $\begin{array}{l}\text { Percentage } \\
\text { Pending, } \\
\text { Dormant, or } \\
\text { Removed } \\
\text { from Court }\end{array}$ & $\begin{array}{l}\text { Disposi } \\
\text { tion } \\
\text { Unclear }\end{array}$ & $\begin{array}{l}\text { Number } \\
\text { of Cases } \\
\text { where } \\
\text { there was } \\
\text { Actual } \\
\text { Recovery } \\
\text { to } \\
\text { Corporati } \\
\text { on }^{4}\end{array}$ \\
\hline \multirow[t]{3}{*}{1932} & $\begin{array}{l}\text { First } \\
\text { Depart } \\
\text { ment } \\
\text { (Manh } \\
\text { attan/ } \\
\text { Bronx } \\
\text { ) }\end{array}$ & 84 & $\begin{array}{l}32.14 \% \\
(21 \\
\text { Settleme } \\
\text { nts, } 2 \\
\text { Private } \\
\text { Settleme } \\
\text { nts, } 3 \\
\text { Nominal } \\
\text { Settleme } \\
\text { nts, and } \\
1 \\
\text { Judgme } \\
\text { nt) }\end{array}$ & $11.90 \%(10)$ & $8.33 \%(7)$ & $\begin{array}{l}35.71 \% \text { (2 } \\
\text { Pending, } 2 \\
\text { Removed, } 4 \\
\text { Dormant, } 2 \\
\text { Action } \\
\text { Enjoined, } \\
20 \\
\text { Discontinue } \\
\text { d) }\end{array}$ & $\begin{array}{l}11.90 \% \\
(10)\end{array}$ & $\begin{array}{l}1.19 \% \\
\text { (1) }\end{array}$ \\
\hline & SDNY & 14 & $\begin{array}{l}7.14 \% \\
(1)\end{array}$ & $28.57 \%(4)$ & $7.14 \%(1)$ & $\begin{array}{l}57.14 \%(2 \\
\text { Remanded } \\
\text { to Sup. Ct. } \\
\text { and } 6 \\
\text { Discontinue } \\
\text { d) }\end{array}$ & $\begin{array}{l}0.00 \% \\
(0)\end{array}$ & $\begin{array}{l}0.00 \% \\
(0)\end{array}$ \\
\hline & $\begin{array}{l}\text { Kings } \\
\text { County }\end{array}$ & 0 & & & & & & \\
\hline
\end{tabular}

${ }^{1}$ From Wood Report Appendix.

${ }^{2}$ Successful suits include judgments in favor of the plaintiff and settlements.

${ }^{3}$ Strike Suit here is defined as suits that did not for whatever reason go beyond a dismissal or summary judgment in favor of the defendant.

${ }^{4}$ Some settlements and judgments were nominal pittances while others were rather monumental victories for the plaintiffs (in the millions of dollars). 


\begin{tabular}{|c|c|c|c|c|c|c|c|c|}
\hline 1933 & $\begin{array}{l}\text { First } \\
\text { Depart } \\
\text { ment } \\
\text { (Manh } \\
\text { attan/ } \\
\text { Bronx } \\
\text { ) }\end{array}$ & 145 & $\begin{array}{l}27.59 \% \\
(31 \\
\text { Settleme } \\
\text { nts, } 3 \\
\text { Private } \\
\text { Settleme } \\
\text { nts, } 2 \\
\text { Nominal } \\
\text { Sttleme } \\
\text { nts, } 3 \\
\text { Judgme } \\
\text { nts, and } \\
1 \\
\text { Settleme } \\
\text { nt After } \\
\text { Judgme } \\
\text { nt) }\end{array}$ & $\begin{array}{l}10.34 \%(13, \\
1 \\
\text { Consensual } \\
\text { Dismissal, } \\
\text { and } 1 \\
\text { Consensual } \\
\text { Dismissal } \\
\text { on the } \\
\text { Merits) }\end{array}$ & $7.59 \%(11)$ & $\begin{array}{l}24.14 \% \text { (1 } \\
\text { Dormant, } 5 \\
\text { Removed, } \\
\text { and } 29 \\
\text { Discontinue } \\
\text { d) }\end{array}$ & $\begin{array}{l}30.34 \% \\
(44)\end{array}$ & $\begin{array}{l}5.52 \% \\
(8)\end{array}$ \\
\hline & SDNY & 7 & $\begin{array}{l}14.29 \% \\
(1 \\
\text { Settleme } \\
n t)\end{array}$ & $0.00 \%(0)$ & $0.00 \%(0)$ & $\begin{array}{l}85.71 \% \text { (1 } \\
\text { Remand to } \\
\text { Sup. Ct. and } \\
5 \\
\text { Discontinue } \\
\text { d) }\end{array}$ & $\begin{array}{l}0.00 \% \\
(0)\end{array}$ & $\begin{array}{l}14.29 \% \\
\text { (1) }\end{array}$ \\
\hline & $\begin{array}{l}\text { Kings } \\
\text { Count } \\
\mathrm{y}\end{array}$ & 0 & & & & & & \\
\hline 1934 & $\begin{array}{l}\text { First } \\
\text { Depart } \\
\text { ment } \\
\text { (Manh } \\
\text { attan/ } \\
\text { Bronx } \\
\text { ) }\end{array}$ & 77 & $\begin{array}{l}22.08 \% \\
(15 \\
\text { Settleme } \\
\text { nts, } 1 \\
\text { Nominal } \\
\text { Settleme } \\
\text { nt } 1 \\
\text { Judgme } \\
\text { nt but } \\
\text { Defenda } \\
\text { nt was } \\
\text { Judgme } \\
\text { nt } \\
\text { Proof) } \\
\text { Note } \\
\text { that one } \\
\text { settleme }\end{array}$ & $\begin{array}{l}10.39 \% \text { ( } 7 \\
\text { and } 1 \text { was } \\
\text { because } \\
\text { Def. was in } \\
\text { Bankruptcy } \\
\text { Court) }\end{array}$ & $\begin{array}{l}11.69 \% \text { (8 } \\
\text { Judgments } \\
\text { and } 1 \\
\text { Reversal) }\end{array}$ & $\begin{array}{l}29.87 \% \text { (1 } \\
\text { Pending, } 1 \\
\text { Dormant, } 3 \\
\text { Transferred, } \\
\text { and } 18 \\
\text { Discontinue } \\
\text { d) }\end{array}$ & $\begin{array}{l}25.97 \% \\
(20)\end{array}$ & $\begin{array}{l}1.30 \% \\
\text { (1) }\end{array}$ \\
\hline
\end{tabular}




\begin{tabular}{|c|c|c|c|c|c|c|c|c|}
\hline & & & $\begin{array}{l}\text { nt } \\
\text { disposed } \\
\text { of the } \\
\text { BOD. }\end{array}$ & & & & & \\
\hline & SDNY & 6 & $\begin{array}{l}50.00 \% \\
(3 \\
\text { Settleme } \\
\text { nts) } \\
\end{array}$ & $33.33 \%(2)$ & $0.00 \%(0)$ & $\begin{array}{l}16.67 \% \text { (1 } \\
\text { Discontinue } \\
\text { d) }\end{array}$ & $\begin{array}{l}0.00 \% \\
(0)\end{array}$ & $\begin{array}{l}0.00 \% \\
(0)\end{array}$ \\
\hline & $\begin{array}{l}\text { Kings } \\
\text { Count } \\
\text { y }\end{array}$ & 0 & & & & & & \\
\hline \multirow[t]{3}{*}{1935} & $\begin{array}{l}\text { First } \\
\text { Depart } \\
\text { ment } \\
\text { (Manh } \\
\text { attan/ } \\
\text { Bronx } \\
\text { ) }\end{array}$ & 139 & $\begin{array}{l}33.09 \% \\
(40 \\
\text { Settleme } \\
\text { nts, } 4 \\
\text { Nominal } \\
\text { Settleme } \\
\text { nts, and } \\
2 \\
\text { Judgme } \\
\text { nts) }\end{array}$ & $\begin{array}{l}10.79 \% \text { (14 } \\
\text { and } 1 \text { by } \\
\text { Consent) }\end{array}$ & $4.32 \%(6)$ & $\begin{array}{l}37.41 \% \text { (1 } \\
\text { Pending, } 6 \\
\text { Removed, } 1 \\
\text { Transferred, } \\
8 \text { Dormant, } \\
\text { and } 36 \\
\text { Discontinue } \\
\text { d) }\end{array}$ & $\begin{array}{l}14.39 \% \\
(20)\end{array}$ & $\begin{array}{l}15.79 \% \\
\text { (3) }\end{array}$ \\
\hline & SDNY & 10 & $\begin{array}{l}0.00 \% \\
(0)\end{array}$ & $\begin{array}{l}10.00 \%(1 \\
\text { Comp. } \\
\text { Dismissed) }\end{array}$ & $0.00 \%(0)$ & $\begin{array}{l}90.00 \% \text { (1 } \\
\text { Remand to } \\
\text { Sup. Ct. and } \\
8 \\
\text { Discontinue } \\
\text { d) }\end{array}$ & $\begin{array}{l}0.00 \% \\
(0)\end{array}$ & $\begin{array}{l}0.00 \% \\
(0)\end{array}$ \\
\hline & $\begin{array}{l}\text { Kings } \\
\text { Count } \\
\mathrm{y}\end{array}$ & 0 & & & & & & \\
\hline 1936 & $\begin{array}{l}\text { First } \\
\text { Depart } \\
\text { ment } \\
\text { (Manh } \\
\text { attan/ } \\
\text { Bronx } \\
\text { ) }\end{array}$ & 82 & $\begin{array}{l}25.61 \% \\
(19 \\
\text { Settleme } \\
\text { nts, } 1 \\
\text { Judgme } \\
\text { nt, and 1 } \\
\text { Settleme } \\
\text { nt After } \\
\text { Judgme } \\
\text { nt) }\end{array}$ & $14.63 \%(12)$ & $6.10 \%(5)$ & $\begin{array}{l}43.90 \% \text { (1 } \\
\text { Pending, } 1 \\
\text { Dormant, } \\
10 \\
\text { Removed, } \\
\text { and } 24 \\
\text { Discontinue } \\
\text { d) }\end{array}$ & $\begin{array}{l}9.76 \% \\
(8)\end{array}$ & $\begin{array}{l}2.44 \% \\
(2)\end{array}$ \\
\hline & SDNY & 9 & $\begin{array}{l}33.33 \% \\
\text { (3 }\end{array}$ & $55.55 \%(5)$ & $11.11 \%(1)$ & $0.00 \%(0)$ & $\begin{array}{l}0.00 \% \\
(0)\end{array}$ & $\begin{array}{l}11.11 \% \\
\text { (1) }\end{array}$ \\
\hline
\end{tabular}




\begin{tabular}{|c|c|c|c|c|c|c|c|c|}
\hline & & & $\begin{array}{l}\text { Settleme } \\
\text { nts) }\end{array}$ & & & & & \\
\hline & $\begin{array}{l}\text { Kings } \\
\text { Count } \\
\text { y }\end{array}$ & 0 & & & & & & \\
\hline \multirow[t]{3}{*}{1937} & $\begin{array}{l}\text { First } \\
\text { Depart } \\
\text { ment } \\
\text { (Manh } \\
\text { attan/ } \\
\text { Bronx } \\
\text { ) }\end{array}$ & 73 & $\begin{array}{l}28.77 \% \\
(18 \\
\text { Settleme } \\
\text { nts, } 1 \\
\text { Nominal } \\
\text { Settleme } \\
\text { nt, and } 2 \\
\text { Judgme } \\
\text { nts) }\end{array}$ & $16.44 \%$ (12) & $15.07 \%(11)$ & $\begin{array}{l}28.77 \% \text { (3 } \\
\text { Dormant, } 2 \\
\text { Removed, } \\
\text { and } 16 \\
\text { Discontinue } \\
\text { d) }\end{array}$ & $\begin{array}{l}10.96 \% \\
(8)\end{array}$ & $\begin{array}{l}2.74 \% \\
(2)\end{array}$ \\
\hline & SDNY & 11 & $\begin{array}{l}27.27 \% \\
(2 \\
\text { Settleme } \\
\text { nts, } 1 \\
\text { Judgme } \\
\text { nt) } \\
\end{array}$ & $18.18 \%(2)$ & $9.09 \%$ (1) & $\begin{array}{l}45.45 \% \text { (1 } \\
\text { Removed, } \\
\text { and } 4 \\
\text { Discontinue } \\
\text { d) }\end{array}$ & $\begin{array}{l}0.00 \% \\
(0)\end{array}$ & $\begin{array}{l}0.00 \% \\
(0)\end{array}$ \\
\hline & $\begin{array}{l}\text { Kings } \\
\text { Count } \\
\mathrm{y}\end{array}$ & 0 & & & & & & \\
\hline 1938 & $\begin{array}{l}\text { First } \\
\text { Depart } \\
\text { ment } \\
\text { (Manh } \\
\text { attan/ } \\
\text { Bronx } \\
\text { ) }\end{array}$ & 101 & $\begin{array}{l}29.70 \% \\
(22 \\
\text { Settleme } \\
\text { nts, } 3 \\
\text { Nominal } \\
\text { Settleme } \\
\text { nts, } 1 \\
\text { Settleme } \\
\text { nt after } \\
\text { Judgme } \\
\text { nt for } \\
\text { Plaintiff, } \\
4 \\
\text { Judgme } \\
\text { nts) }\end{array}$ & $9.90 \%(10)$ & $10.89 \%(11)$ & $\begin{array}{l}31.68 \% \text { (2 } \\
\text { Pending, } 2 \\
\text { Removed or } \\
\text { Transferred, } \\
25 \\
\text { Discontinue } \\
\text { d, and 3 } \\
\text { Dormant) }\end{array}$ & $\begin{array}{l}17.82 \% \\
(15 \text { and } \\
3 \\
\text { Supers } \\
\text { eded by } \\
\text { Rec. } \\
\text { Action) }\end{array}$ & $\begin{array}{l}5.94 \% \\
(6)\end{array}$ \\
\hline & SDNY & 14 & $\begin{array}{l}35.71 \% \\
(4 \\
\text { Settleme } \\
\text { nts and } \\
1\end{array}$ & $14.29 \%(2)$ & $0.00 \%(0)$ & $\begin{array}{l}50.00 \% \text { (2 } \\
\text { Removed or } \\
\text { Remanded, } \\
5 \\
\text { Discontinue }\end{array}$ & $\begin{array}{l}0.00 \% \\
(0)\end{array}$ & $\begin{array}{l}7.14 \% \\
\text { (1) }\end{array}$ \\
\hline
\end{tabular}




\begin{tabular}{|c|c|c|c|c|c|c|c|c|}
\hline & & & $\begin{array}{l}\text { Judgme } \\
\text { nt) }\end{array}$ & & & d) & & \\
\hline & $\begin{array}{l}\text { Kings } \\
\text { Count } \\
\mathrm{y}\end{array}$ & 30 & $\begin{array}{l}26.67 \% \\
(7 \\
\text { Settleme } \\
\text { nts and } \\
1 \\
\text { Judgme } \\
\text { nt) }\end{array}$ & $6.67 \%$ (2) & $10.00 \%$ (3) & $\begin{array}{l}26.67 \% \text { (1 } \\
\text { Pending, } 2 \\
\text { Dormant, } 1 \\
\text { to Referee } \\
\text { and } 4 \\
\text { Discontinue } \\
\text { d) }\end{array}$ & $\begin{array}{l}30.00 \% \\
(9)\end{array}$ & $\begin{array}{l}3.33 \% \\
\text { (1) }\end{array}$ \\
\hline \multirow[t]{3}{*}{1939} & $\begin{array}{l}\text { First } \\
\text { Depart } \\
\text { ment } \\
\text { (Manh } \\
\text { attan/ } \\
\text { Bronx } \\
\text { ) }\end{array}$ & 89 & $\begin{array}{l}17.98 \% \\
(9 \\
\text { Settleme } \\
\text { nts, } 1 \\
\text { Nominal } \\
\text { Settleme } \\
\text { nt, and } 6 \\
\text { Judgme } \\
\text { nts) }\end{array}$ & $20.22 \%(18)$ & $\begin{array}{l}12.36 \%(10 \\
\text { and } 1 \text { on } \\
\text { Consent) }\end{array}$ & $\begin{array}{l}39.33 \% \text { (4 } \\
\text { Pending, } 4 \\
\text { Removed, } \\
23 \\
\text { Discontinue } \\
\text { d, } 2 \\
\text { Dormant } \\
\text { and } 1 \\
\text { Vacated } \\
\text { Service and } \\
1 \text { Dismissed } \\
\text { as to } 3 \\
\text { defendants } \\
\text { and dormant } \\
\text { as to others. }\end{array}$ & $\begin{array}{l}10.11 \% \\
\text { (8 and } \\
1 \text { for } \\
\text { Apprai } \\
\text { sal) }\end{array}$ & $\begin{array}{l}4.49 \% \text { (3 } \\
\text { Payments } \\
\text { and } 1 \\
\text { Failed } \\
\text { Payment) }\end{array}$ \\
\hline & SDNY & 16 & $\begin{array}{l}6.25 \% \\
(1 \\
\text { Settleme } \\
\text { nt) }\end{array}$ & $62.50 \%(10)$ & $12.50 \%$ (2) & $\begin{array}{l}18.75 \% \text { (1 } \\
\text { Pending, 1 } \\
\text { Removed } \\
\text { and 1 } \\
\text { Discontinue } \\
\text { d) }\end{array}$ & $\begin{array}{l}0.00 \% \\
(0)\end{array}$ & $\begin{array}{l}0.00 \% \\
(0)\end{array}$ \\
\hline & $\begin{array}{l}\text { Kings } \\
\text { Count } \\
\mathrm{y}\end{array}$ & 14 & $\begin{array}{l}28.57 \% \\
(4 \\
\text { Judgme } \\
\text { nts) }\end{array}$ & $\begin{array}{l}28.57 \% \text { (3 } \\
\text { and } 1 \\
\text { Motion to } \\
\text { examine } \\
\text { denied) }\end{array}$ & $0.00 \%(0)$ & $\begin{array}{l}28.57 \% \text { (1 } \\
\text { Pending 1 } \\
\text { Removed, } 2 \\
\text { Discontinue } \\
\text { d) }\end{array}$ & $\begin{array}{l}14.29 \% \\
\text { (2) }\end{array}$ & $\begin{array}{l}0.00 \% \\
(0)\end{array}$ \\
\hline 1940 & $\begin{array}{l}\text { First } \\
\text { Depart } \\
\text { ment } \\
\text { (Manh } \\
\text { attan/ } \\
\text { Bronx } \\
\text { ) }\end{array}$ & 132 & $\begin{array}{l}29.55 \% \\
(32 \\
\text { Settleme } \\
\text { nts, } 1 \\
\text { Settled } \\
\text { Nominal } \\
\text { ly, and } 6 \\
\text { Judgme }\end{array}$ & $9.85 \%$ (13) & $12.12 \%(16)$ & $\begin{array}{l}28.03 \% \text { (10 } \\
\text { Pending and } \\
27 \\
\text { Discontinue } \\
\text { d) }\end{array}$ & $\begin{array}{l}20.45 \% \\
(27)\end{array}$ & $\begin{array}{l}3.03 \% \\
\text { (4) }\end{array}$ \\
\hline
\end{tabular}




\begin{tabular}{|c|c|c|c|c|c|c|c|c|}
\hline & & & nts) & & & & & \\
\hline & SDNY & 10 & $\begin{array}{l}20.0 \% \\
(1 \\
\text { Settleme } \\
\text { nt and } 1 \\
\text { Judgme } \\
\text { nt) }\end{array}$ & $40.0 \%$ & $10.0 \%$ & $20.0 \%(2)$ & $\begin{array}{l}10.0 \% \\
(1)\end{array}$ & $\begin{array}{l}0.00 \% \\
(0)\end{array}$ \\
\hline & $\begin{array}{l}\text { Kings } \\
\text { Count } \\
\mathrm{y}\end{array}$ & 17 & $\begin{array}{l}5.88 \% \\
(1)\end{array}$ & $11.76 \%(2)$ & $11.76 \%$ (2) & $\begin{array}{l}29.41 \% \text { (1 } \\
\text { Pending and } \\
4 \\
\text { Discontinue } \\
\text { d) }\end{array}$ & $\begin{array}{l}41.18 \% \\
\text { (7) }\end{array}$ & $\begin{array}{l}0.00 \% \\
(0)\end{array}$ \\
\hline \multirow[t]{3}{*}{1941} & $\begin{array}{l}\text { First } \\
\text { Depart } \\
\text { ment } \\
\text { (Manh } \\
\text { attan/ } \\
\text { Bronx } \\
\text { ) }\end{array}$ & 75 & $\begin{array}{l}16.0 \% \\
(7 \\
\text { Settleme } \\
\text { nts and } \\
5 \\
\text { Judgme } \\
\text { nts }\end{array}$ & $21.33 \%(16)$ & $10.66 \%(8)$ & $\begin{array}{l}27.0 \% \text { (13 } \\
\text { Pending + } \\
14 \\
\text { Discontinue } \\
\text { d) }\end{array}$ & $\begin{array}{l}16.0 \% \\
(12)\end{array}$ & $\begin{array}{l}9.33 \% \\
(7)\end{array}$ \\
\hline & SDNY & 13 & $\begin{array}{l}7.69 \% \\
(1 \\
\text { Settleme } \\
\mathrm{nt})\end{array}$ & $\begin{array}{l}61.54 \%(8) \\
\text { (1 for no } \\
\text { Juris.) }\end{array}$ & $7.69 \%(1)$ & $\begin{array}{l}23.08 \% \text { (2 } \\
\text { Pending) }\end{array}$ & $\begin{array}{l}0.00 \% \\
(0)\end{array}$ & $\begin{array}{l}0.00 \% \\
(0)\end{array}$ \\
\hline & $\begin{array}{l}\text { Kings } \\
\text { Count } \\
\mathrm{y}\end{array}$ & 37 & $\begin{array}{l}27.03 \% \\
(9 \\
\text { Settleme } \\
\text { nts and } \\
1 \\
\text { Judgme } \\
\text { nt) }\end{array}$ & $10.81 \%(4)$ & $5.40 \%(2)$ & $21.62 \%(8)$ & $\begin{array}{l}35.14 \% \\
(13)\end{array}$ & $\begin{array}{l}0.00 \% \\
(0)\end{array}$ \\
\hline \multirow[t]{3}{*}{1942} & $\begin{array}{l}\text { First } \\
\text { Depart } \\
\text { ment } \\
\text { (Manh } \\
\text { attan/ } \\
\text { Bronx } \\
\text { ) } \\
\end{array}$ & 92 & $\begin{array}{l}17.31 \% \\
(16 \\
\text { Settleme } \\
\text { nts and } \\
2 \\
\text { Judgme } \\
\text { nts) }\end{array}$ & $19.23 \%(20)$ & $7.69 \%(8)$ & $16.35 \%(17)$ & $\begin{array}{l}27.88 \% \\
(29)\end{array}$ & $\begin{array}{l}1.92 \% \\
(2)\end{array}$ \\
\hline & SDNY & 14 & $\begin{array}{l}6.67 \% \\
(1 \\
\text { Settleme } \\
n t)\end{array}$ & $\begin{array}{l}33.33 \%(5) \\
\text { (Two b/c } \\
\text { Lack of } \\
\text { Juris.) }\end{array}$ & $13.33 \%(2)$ & $40.00 \%(6)$ & & $0 \%(0)$ \\
\hline & Kings & 26 & $11.54 \%$ & $11.54 \%$ (3) & $7.69 \%(2)$ & $23.08 \%(6)$ & $42.31 \%$ & $3.85 \%$ \\
\hline
\end{tabular}




\begin{tabular}{|l|l|l|l|l|l|l|l|}
\hline $\begin{array}{l}\text { Count } \\
\mathrm{y}\end{array}$ & $\begin{array}{l}\text { (3 } \\
\text { Settleme } \\
\text { nts })\end{array}$ & & & & $(11)$ & (1) \\
\hline
\end{tabular}




\section{Appendix L}

Main Area of Practice by Size of Firm ${ }^{1}, 1960$

\begin{tabular}{|c|c|c|c|c|}
\hline $\begin{array}{l}\text { Main Area of } \\
\text { Practice }\end{array}$ & Large Firm & Medium Firm & Small Firm & Solo Practice \\
\hline Business & $68 \%$ & $66 \%$ & $27 \%$ & $36 \%$ \\
\hline Probate & $23 \%$ & $20 \%$ & $17 \%$ & $15 \%$ \\
\hline Real Estate & $5 \%$ & $2 \%$ & $18 \%$ & $17 \%$ \\
\hline Personal Injury & $2 \%$ & $6 \%$ & $26 \%$ & $22 \%$ \\
\hline $\begin{array}{l}\text { Criminal, } \\
\text { Matrimonial, } \\
\text { and Worker?s } \\
\text { Comp }\end{array}$ & $2 \%$ & $4 \%$ & $11 \%$ & $9 \%$ \\
\hline No Answer & $0 \%$ & $2 \%$ & $1 \%$ & $1 \%$ \\
\hline Total & $\begin{array}{l}100 \% \text { (60 } \\
\text { Reporting) }\end{array}$ & $\begin{array}{l}100 \% \text { (204 } \\
\text { Reporting) }\end{array}$ & $\begin{array}{l}100 \% \text { (161 } \\
\text { Reporting) }\end{array}$ & $\begin{array}{l}100 \% \text { (376 } \\
\text { Reporting) }\end{array}$ \\
\hline
\end{tabular}

\footnotetext{
${ }^{1}$ Carlin at 25.
} 


\section{Appendix M}

Individual Clients Mainly Jewish ${ }^{1}, 1960$

\begin{tabular}{|l|l|l|l|l|}
\hline & Large Firm (15+) & Medium (5-14) & Small (2-4) & Solo Practice \\
\hline $\begin{array}{l}\text { Individual } \\
\text { Clients Mainly } \\
\text { Jewish }\end{array}$ & $14 \%$ & $34 \%$ & $46 \%$ & $44 \%$ \\
\hline
\end{tabular}

\footnotetext{
${ }^{1}$ Carlin at 24.
} 
Net Income Per Family ${ }^{1}$

\begin{tabular}{|l|l|l|l|l|}
\hline & 1944 & $\begin{array}{l}\text { In 2002 } \\
\text { Dollars }\end{array}$ & $2001^{4}$ & $\begin{array}{l}\text { In 2002 } \\
\text { Dollars }\end{array}$ \\
\hline $\begin{array}{l}\text { United States } \\
(\text { Median })^{6}\end{array}$ & 2,533 & $25,876.90$ & $43,388.63$ & $44,050.31$ \\
\hline & & & & \\
\hline & & & & \\
\hline
\end{tabular}

${ }^{1}$ There are two forms of determining the "average" income. The first is the per capita income which is simply the total income of all persons in the area divided by the number of individuals or families in the same area. The second is simply taking the median income which is a function of the highest and lowest incomes. Median is that number that divides the group into two equal parts. See Statistical Abstract of the United States (1949 at 12). For any income table, usage of mean (per capita) and median are mutually exclusive.

${ }^{2}$ The average number of people in families has fluctuated. These statistics use an average number of

people per family. In 1944, this number was 3.54. Historical Statistics of the United States (Dept. of Commerce 1960 at 166).

${ }^{3}$ Multiplier Based on U.S. Department of Labor online inflation adjuster found at http://www.bls.gov/cpi/home.htm\#data. The multiplier was about 10.21591 from 1944 to 2002.

${ }^{4}$ From Statistical Abstract of the United States: 2001 (Dept. of Commerce 2001 at 436). Household Income from 1999. Adjusted to 2001 dollars by using Multiplier Based on U.S. Department of Labor online inflation adjuster found at http://www.bls.gov/cpi/home.htm\#data. The multiplier was about 1.06303 from 1999 to 2001.

${ }^{5}$ Adjusted to 2002 dollars by using Multiplier Based on U.S. Department of Labor online inflation adjuster found at http://www.bls.gov/cpi/home.htm\#data. The multiplier was about 1.01525 from 2001 to 2002.

${ }^{6}$ Statistical Abstract of the United States (1949 at 290). 


\begin{tabular}{|l|l|l|l|l|}
\hline New York & M: $2,369.36^{7}$ & M: $22,399.61$ & $42,582.86$ & $43,232.25$ \\
\hline & W: $1,260.11$ & W: $12,873.15$ & & \\
\hline
\end{tabular}

Net Income Per Individual

\begin{tabular}{|l|l|l|l|l|}
\hline & $1946^{1}$ & $\begin{array}{l}\text { In 2002 } \\
\text { Dollars }^{2}\end{array}$ & $2001^{3}$ & $\begin{array}{l}\text { In 2002 } \\
\text { Dollars }\end{array}$ \\
\hline United States & 1,213 & $24,205.17$ & $30,520.58$ & $30,986.02$ \\
\hline & & & & \\
\hline & & & & \\
\hline New York & 1,651 & $15,223.06$ & $35,530.21$ & $36,072.04$ \\
\hline
\end{tabular}

${ }^{7}$ Figures per 1950 Census, Vol. II Characteristics of the Population, Part 32, Page 32-446. The 1940 Census was the first census using net incomes, and the 1950 census was the first census using families as economic units. The 1950 census numbers here use 1949 estimates of net incomes for persons (males and females separately) as heads of families. Of course, this information fails to adjust for families that have two incomes while commonplace today was still rare in the late 1940s. Figures found were adjusted downward by using U.S. Department of Labor online inflation adjuster found at http://www.bls.gov/cpi/home.htm\#data. The multiplier was about 0.73950 from 1949 to 1944.

${ }^{1}$ Per Capita is Based on Closest Year (1946).

${ }^{2}$ Multiplier Based on U.S. Department of Labor online inflation adjuster found at http://www.bls.gov/cpi/home.htm\#data. The multiplier was about 9.22051 from 1946 to 2002.

${ }^{3}$ From Statistical Abstract of the United States: 2001 (Dept. of Commerce 2001 at 426). Net Income from 2000. Adjusted to 2001 dollars by using Multiplier Based on U.S. Department of Labor online inflation adjuster found at http://www.bls.gov/cpi/home.htm\#data. The multiplier was about 1.02846 from 2000 to 2001.

${ }^{4}$ Adjusted to 2001 dollars by using Multiplier Based on U.S. Department of Labor online inflation adjuster found at http://www.bls.gov/cpi/home.htm\#data. The multiplier was about 9.22051 from 2001 to 2002. 